\title{
Interventions to Ameliorate the Psychosocial Effects of the COVID-19 Pandemic on Children-A Systematic Review
}

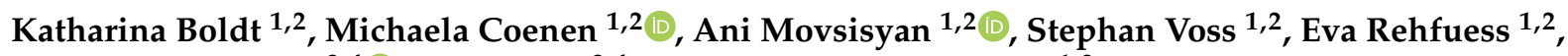 \\ Angela M. Kunzler ${ }^{3,4}{ }^{\circledR}$, Klaus Lieb ${ }^{3,4}$ and Caroline Jung-Sievers ${ }^{1,2, *}$ \\ 1 Institute for Medical Information Processing, Biometry and Epidemiology—IBE, Chair of Public Health and \\ Health Services Research, LMU Munich, Elisabeth-Winterhalter-Weg 6, 81377 Munich, Germany; \\ kboldt@ibe.med.uni-muenchen.de (K.B.); coenen@ibe.med.uni-muenchen.de (M.C.); \\ ani.movsisyan@ibe.med.uni-muenchen.de (A.M.); svoss@ibe.med.uni-muenchen.de (S.V.); \\ rehfuess@ibe.med.uni-muenchen.de (E.R.) \\ 2 Pettenkofer School of Public Health, 81377 Munich, Germany \\ 3 Department of Psychiatry and Psychotherapy, University Medical Center, 55131 Mainz, Germany; \\ Angela.Kunzler@lir-mainz.de (A.M.K.); klaus.lieb@unimedizin-mainz.de (K.L.) \\ 4 Leibniz Institute for Resilience Research (LIR), 55122 Mainz, Germany \\ * Correspondence: cjungsievers@ibe.med.uni-muenchen.de
}

check for updates

Citation: Boldt, K.; Coenen, M.; Movsisyan, A.; Voss, S.; Rehfuess, E.; Kunzler, A.M.; Lieb, K.; Jung-Sievers, C. Interventions to Ameliorate the Psychosocial Effects of the COVID-19 Pandemic on Children-A Systematic Review. Int. J. Environ. Res. Public Health 2021, 18, 2361. https:// doi.org/10.3390/ijerph18052361

Academic Editor: Alan Apter

Received: 21 January 2021

Accepted: 23 February 2021

Published: 28 February 2021

Publisher's Note: MDPI stays neutral with regard to jurisdictional claims in published maps and institutional affiliations.

Copyright: (c) 2021 by the authors. Licensee MDPI, Basel, Switzerland. This article is an open access article distributed under the terms and conditions of the Creative Commons Attribution (CC BY) license (https:// creativecommons.org/licenses/by/ $4.0 /)$.

\begin{abstract}
The aim of this study was to identify interventions targeting children and their caregivers to reduce psychosocial problems in the course of the COVID-19 pandemic and comparable outbreaks. The review was performed using systematic literature searches in MEDLINE, Embase, PsycINFO and COVID-19-specific databases, including the CDC COVID-19 Research Database, the World Health Organisation (WHO) Global Database on COVID-19 Research and the Cochrane COVID-19 Study Register, ClinicalTrials.gov, the EU Clinical Trials Register and the German Clinical Trials Register (DRKS) up to 25th September 2020. The search yielded 6657 unique citations. After title/abstract and full text screening, 11 study protocols reporting on trials planned in China, the US, Canada, the UK, and Hungary during the COVID-19 pandemic were included. Four interventions targeted children $\geq 10$ years directly, seven system-based interventions targeted the parents and caregivers of younger children and adolescents. Outcome measures encompassed mainly anxiety and depressive symptoms, different dimensions of stress or psychosocial well-being, and quality of supportive relationships. In conclusion, this systematic review revealed a paucity of studies on psychosocial interventions for children during the COVID-19 pandemic. Further research should be encouraged in light of the expected demand for child mental health management.
\end{abstract}

Keywords: COVID-19; pandemic; child; mental health; intervention

\section{Introduction}

Crises such as disease outbreaks are usually accompanied with stress and uncertainty throughout the whole population. However, depending on the character of a disease outbreak, particular challenges present in specific vulnerable groups. In the context of the SARS-CoV-2 outbreak, which has been officially declared a pandemic by the World Health Organization (WHO) as of 11 March 2020, children and families are particularly affected by negative consequences. These consequences encompass containment measures, such as childcare and school closures with separation and isolation from children's social groups and friends, contact restrictions, quarantines, the loss of freedom and opportunities for movement and play, increased boredom, the discrimination against affected families, insecurity of adult caregivers with increased familiar stress and domestic conflicts, adverse effects on children's educational opportunities and impacts on parent's employment [1-3].

Hence, increased anxiety and depression rates are common responses among children and adolescents in affected countries [2,4-6]. Depending on the study and setting, the 
proportion of children and adolescents reporting mental health issues above risk thresholds of distress, particularly anxiety and depression, can range up to $60 \%$ [7-9]. Children with pre-existing mental health conditions and of more deprived populations seem to be particularly vulnerable in this regard. At the same time, psychiatric attendances seem to be reduced in the pandemic which can be interpreted as unmet health care needs.

Since children are at a particularly vulnerable stage of life, special attention should be paid to psychosocial interventions for children and adolescents in crisis situations with regard to mental illness prevention and mental health promotion. Possible interventions may target, for example, the ability to build resilience, express and regulate emotions, pursue meaningful and relaxing activities, and thus develop alternatives to risk behaviors [10].

These interventions may help combat mental illness in the future and prevent the enormous personal and societal burdens associated with it. In this context, early engagement seems to be crucial to prevent long-term consequences such as substance abuse, lower educational achievement, and development of violence [11,12].

As in other crises, WHO and other organizations emphasize the importance of multisectoral, early psychosocial support for the young and provide guiding information materials on the topic [13-15].

However, to date, evidence on the existence, specific approaches, content, and possible effects of psychosocial interventions to prevent or manage mental health outcomes of children in the course of the COVID-19 pandemic is sparse. The objective of this review was therefore to identify interventions that target children, their caregivers and/or families, in order to reduce the psychosocial impacts caused by the COVID-19 and comparable disease outbreaks, as well as associated control measures (e.g., quarantine).

\section{Materials and Methods}

This systematic review was performed based on a protocol pre-registered on the Open Science Framework (OSF): https: / / osf.io/chpvk.

\subsection{Search Methods for the Identification of Studies}

We performed searches on 25 September 2020 in MEDLINE, Embase, and PsycINFO, using a combination of terms related to disease outbreaks and their spread, the population of interest, psychosocial outcomes and interventions (see Appendices A-I). We additionally searched COVID-19-specific databases, including the Centers for Disease Control and Prevention (CDC) COVID-19 Research Articles Downloadable Database, the WHO Global Database on COVID-19 Research and the Cochrane COVID-19 Study Register, as well as clinical trials registries, namely ClinicalTrials.gov, the EU Clinical Trials Register and the German Clinical Trials Register (DRKS).

Our search strategy was reviewed by an experienced information specialist. Database searches were limited to studies published in English, German, Russian, and French. No restrictions based on the year of publication and publication format were applied.

Inclusion and exclusion criteria for studies are described in Table 1.

Table 1. Inclusion and exclusion criteria.

\begin{tabular}{|c|c|c|}
\hline & Inclusion Criteria & Exclusion Criteria \\
\hline \multirow[b]{3}{*}{ Population } & \multirow{2}{*}{$\begin{array}{l}\text { Children aged } 0-17 \text { years and/or their } \\
\text { families/primary caregivers }\end{array}$} & Children and/or their families/primary caregivers \\
\hline & & - $\quad$ In pandemic situations with haemorrhagic \\
\hline & $\begin{array}{l}\text { - Living in low-, middle- or high-income } \\
\text { countries with COVID-19/SARS/MERS } \\
\text { or H1N1 influenza pandemic or outbreak }\end{array}$ & $\begin{array}{l}\text { fevers (including Dengue and Ebola) } \\
\text { - } \quad \text { Admitted to hospital wards } \\
\text { - With other acute viral and bacterial } \\
\text { respiratory infections }\end{array}$ \\
\hline
\end{tabular}


Table 1. Cont.

\begin{tabular}{|c|c|c|}
\hline & Inclusion Criteria & Exclusion Criteria \\
\hline Intervention/exposure & $\begin{array}{l}\text { Interventions aimed at ameliorating the } \\
\text { psychosocial effects of pandemic } \\
\text { situationsIntervention types, e.g.,: } \\
\text { - } \quad \text { Training courses } \\
-\quad \text { Exercises } \\
\text { - } \quad \text { Teaching materials and information } \\
\text { - } \quad \text { Support groups } \\
\text { Intervention delivery modes, e.g.,: } \\
-\quad \text { Face to face, online, or smartphone-based } \\
\text { - } \quad \text { Individual, group, population-based } \\
-\quad \text { Child-based, system-basted }\end{array}$ & $\begin{array}{l}\text { Interventions aimed at } \\
-\quad \text { Behavioral modification of disease spread } \\
\text { (containment, protection, mitigation) } \\
\text { - } \quad \text { Inpatient settings } \\
\text { - } \quad \begin{array}{l}\text { Patients with specific diseases, e.g., } \\
\text { chronic diseases }\end{array}\end{array}$ \\
\hline Comparison & \begin{tabular}{ll}
\multicolumn{2}{l}{ Treatment as usual (TAU) } \\
- & Alternative treatment \\
- & Waitlist control \\
- & No treatment
\end{tabular} & / \\
\hline Outcomes & $\begin{array}{ll}\text { Primary health outcomes, i.e.,: } \\
- & \text { Self-efficacy } \\
- & \text { Behavioral problems } \\
- & \text { Mental health problems } \\
- & \text { Stress } \\
- & \text { Maltreatment } \\
\text { Secondary implementation outcomes, e.g.,: } \\
- & \text { Attendance } \\
- & \text { Engagement }\end{array}$ & $\begin{array}{l}\text { Somatic outcomes of SARS-CoV-1, SARS-CoV-2, } \\
\text { MERS-CoV-1, and H1N1 influenza infectionAny } \\
\text { other outcomes not listed above, e.g.,: } \\
\text { - } \quad \text { Physical activity } \\
\text { - } \quad \text { Concentration } \\
\text { - } \quad \text { School grades }\end{array}$ \\
\hline Study designs & $\begin{array}{ll}\text { Any study or protocol using an empirical } \\
\text { study design, including: } \\
\text { - } \quad \text { Randomized controlled trials } \\
\text { - } \quad \text { Cohort studies } \\
\text { - } \quad \text { Cross-sectional studies } \\
\text { - } \quad \text { Qualitative studies } \\
\text { - } \quad \text { Mixed-methods studies } \\
\text { - } \quad \text { Case series with } \geq 10 \text { persons } \\
\text { - } \quad \text { Case series with }<10 \text { persons (only for } \\
\quad \text { COVID-19, SARS, and MERS) }\end{array}$ & $\begin{array}{l}\text { Non-empirical studies, including: } \\
-\quad \text { Commentaries } \\
-\quad \text { Letters } \\
-\quad \text { Editorials } \\
-\quad \text { Overviews } \\
\text { Mechanistic dataAnimal studiesLaboratory studies }\end{array}$ \\
\hline
\end{tabular}

\subsection{Study Selection}

After removal of duplicate studies, we performed a multistage screening process to select those studies which met the inclusion criteria:

- $\quad$ Stage 1, screening of titles and abstracts: One review author screened the titles and abstracts of all identified records (KB). Twenty percent of all titles and abstracts were independently assessed by a second review author (CJS, AM, MC, SV) and in case of disagreement discussed with a third reviewer (CJS, AM, MC, SV). At this stage, an inclusive approach was adopted and all unclear studies were taken forward to full text screening.

- $\quad$ Stage 2, screening of full texts: Two review authors (KB, CJS, AM, MC, SV) independently screened the full texts of all studies selected by at least one review author at stage 1 . Uncertainties were resolved through discussion or by consulting a third review author (KB, CJS, AM, MC, SV). 
EndNote was used to collect and de-duplicate the studies. For the screening of titles and abstracts we used Rayyan web-based application for facilitating citation screening for systematic reviews [16]. At stage 2 of the screening process, we documented the reasons for exclusion using Microsoft Excel spreadsheets.

\subsection{Data Extraction, Management, and Synthesis}

One review author (KB) extracted study data and characteristics to an Excel-based data extraction form (see Appendix J). A second review author (CJS) checked for completeness and correctness. We synthesized the findings of the included studies narratively and with tables.

\section{Results}

\subsection{Results of the Search}

Overall, our systematic searches yielded 6657 unique records. After title and abstract screening, 279 records were taken forward for full text screening (Figure 1). Of these, 260 full text papers were assessed for eligibility. Most of these were non-empirical studies such as commentaries, editorials, reviews, news and adapted recommendations that emphasize the importance of preparing for a mental health crisis in the context and aftermath of the COVID-19 pandemic. The full texts of 19 papers could not be retrieved.

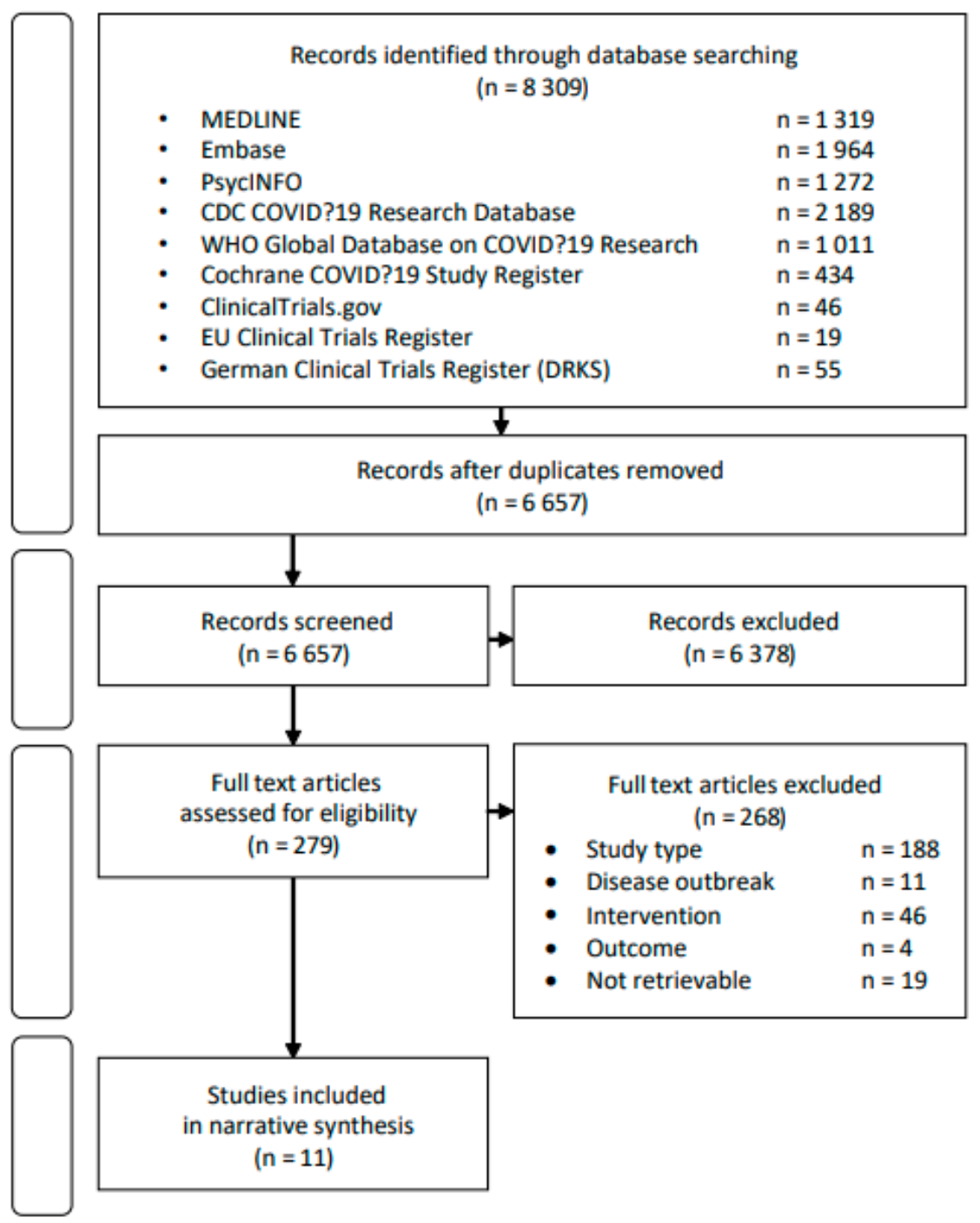

Figure 1. Preferred Reporting Items for Systematic Reviews and Meta-Analyses (PRISMA) flow chart. 


\subsection{Included Studies}

After title/abstract and full text screening, 11 papers met our eligibility criteria. These papers are summarized in Tables 2 and 3. All manuscripts report on study protocols. Four protocols were registered in China, three in the US and two in Canada, and one in the UK and one in Hungary. All studies are planned in the COVID-19 setting and none identified in previous SARS, MERS, or H1N1 influenza outbreaks. Four study interventions addressed children directly; in two and five studies the interventions were targeted at children plus parents/caregivers combined or at parents/caregivers only. Two interventions are intended for face-to-face delivery, nine studies are designed as digital interventions.

Four of the included papers were study protocols for randomized controlled trials (RCTs) on digital interventions for children aged $\geq 10$ years that aimed to reduce symptoms of anxiety or to improve the emotional well-being or the ability to support others during the COVID-19 outbreak.

The study protocol by Chen [17] aims at assessing the effectiveness of an online Solution Focused Brief Therapy (SFBT) for adolescents. SFBT is a short-term psychotherapy option that builds on positive emotion-evoking, resource- and future-oriented principles of behavior modification [18]. The second included protocol by Zheng [19] plans to test a live-streaming application for children that offers a Recess and Exercise Advocate Program (REAP) during online learning classes in the time of school closure and home confinement. REAP is a digital platform that allows students to watch stay-at-home workouts, record short videos, or take photos related to their own physical exercise and upload these to the app, using smartphones. Tymofiyeva [20] aims at evaluating the efficacy of Training for Awareness Resilience and Action (TARA), a neuroscience-based program for adolescent anxiety and depression informed by mindfulness-based therapy, yoga and modern psychotherapeutic techniques [21]. Pavarini [22] plans to co-produce and deliver an online peer support training together with young people and the peer support charity YouthEra. Although some of these studies, once completed, may include some adolescents aged 18 years and above (thus outside of our inclusion criteria), the majority of study participants will likely be within our age range of $0-17$ years as defined by the inclusion criteria.

Table 2. Characteristics of included studies.

\begin{tabular}{|c|c|c|c|c|c|c|}
\hline First Author(s) & Journal/Database & Date Published & $\begin{array}{l}\text { Planned Study } \\
\text { Completion Date }\end{array}$ & $\begin{array}{c}\text { Study Type According } \\
\text { to Protocol }\end{array}$ & Population and Context & Country \\
\hline Chen S [17] & Trials & 13 May 2020 & NR & $\begin{array}{l}\text { Study protocol for a } \\
\text { randomized delayed } \\
\text { crossover open-label } \\
\text { controlled trial }\end{array}$ & $\begin{array}{c}\text { Target group: Children } \\
\text { (11-18 years) } \\
\text { Planned number: } 76 \\
\text { Condition/context: } \\
\text { Manifesting anxiety } \\
\text { symptoms, Generalised } \\
\text { Anxiety Disorder-7 } \\
\text { score } \geq 10 \\
\end{array}$ & China, Beijing \\
\hline Zheng Y [19] & ClinicalTrials.gov & 16 March 2020 & 29 March 2020 & $\begin{array}{l}\text { Study protocol for a } \\
\text { cluster-randomized } \\
\text { controlled trial }\end{array}$ & $\begin{array}{c}\text { Target group: Children } \\
\text { (12-13 years) } \\
\text { Planned number: } 954 \\
\text { Condition/context: } \\
\text { Under home } \\
\text { confinement, enrolled in } \\
\text { online learning courses }\end{array}$ & China \\
\hline $\begin{array}{c}\text { Tymofiyeva } \\
\text { O [20] }\end{array}$ & ClinicalTrials.gov & 14 September 2020 & 20 May 2020 & $\begin{array}{l}\text { Study protocol for a } \\
\text { randomized group } \\
\text { treatment, open-label, } \\
\text { waitlist-controlled } \\
\text { clinical trial }\end{array}$ & $\begin{array}{c}\text { Target group: Children } \\
\text { (14-18 years) } \\
\text { Planned number: } 21 \\
\text { Condition/context: NR }\end{array}$ & US, California \\
\hline Pavarini G [22] & ISRCTN registry & 29 May 2020 & 10 July 2020 & $\begin{array}{l}\text { Study protocol for a } \\
\text { pilot randomized } \\
\text { controlled trial }\end{array}$ & $\begin{array}{c}\text { Target group: Children } \\
\text { (16-18 years) } \\
\text { Planned number: } 100 \\
\text { Condition/context: NR }\end{array}$ & UK \\
\hline
\end{tabular}


Table 2. Cont.

\begin{tabular}{|c|c|c|c|c|c|c|}
\hline First Author(s) & Journal/Database & Date Published & $\begin{array}{l}\text { Planned Study } \\
\text { Completion Date }\end{array}$ & $\begin{array}{l}\text { Study Type According } \\
\text { to Protocol }\end{array}$ & Population and Context & Country \\
\hline Green S [23] & ClinicalTrials.gov & 3 August 2020 & 1 August 2022 & $\begin{array}{l}\text { Study protocol for an } \\
\text { open-label clinical trial }\end{array}$ & $\begin{array}{l}\text { Target group: Women } \\
\text { (18-45 years) } \\
\text { Planned number: } 120 \\
\text { Condition/context: } \\
\text { Pregnant or up to six } \\
\text { months postpartum, } \\
\text { primary diagnosis of an } \\
\text { anxiety disorder }\end{array}$ & $\begin{array}{l}\text { Canada, } \\
\text { Ontario }\end{array}$ \\
\hline Huang HF [24] & $\begin{array}{c}\text { International } \\
\text { Clinical Trials } \\
\text { Registry Platform } \\
\text { (ICTRP) }\end{array}$ & 31 May 2020 & 1 April 2022 & $\begin{array}{l}\text { Study protocol for a } \\
\text { multi-center randomized } \\
\text { controlled trial }\end{array}$ & $\begin{array}{c}\text { Target group: Women } \\
\text { (18 + years) } \\
\text { Planned number: } 300 \\
\text { Condition/context: } \\
\text { Pregnant, Edinburgh } \\
\text { Postnatal Depression } \\
\text { Scale score }>9 \text { during the } \\
\text { third trimester }\end{array}$ & $\begin{array}{l}\text { China, } \\
\text { Shanghai }\end{array}$ \\
\hline Monga S [25] & ClinicalTrials.gov & 29 May 2020 & 1 June 2021 & $\begin{array}{l}\text { Study protocol for an } \\
\text { open-label clinical trial }\end{array}$ & $\begin{array}{c}\text { Target group: Children } \\
\text { (12-17 years) } \\
\text { Planned number: } 20 \\
\text { Condition/context: } \\
\text { Primary diagnosis of an } \\
\text { anxiety disorder }\end{array}$ & $\begin{array}{l}\text { Canada, } \\
\text { Ontario }\end{array}$ \\
\hline $\begin{array}{l}\text { Ehrenreich-May } \\
\text { J [26] }\end{array}$ & ClinicalTrials.gov & 16 June 2020 & 7 November 2020 & $\begin{array}{l}\text { Study protocol for a } \\
\text { randomized open-label } \\
\text { clinical trial }\end{array}$ & $\begin{array}{l}\text { Target group: Parents } \\
\text { (18+ years) } \\
\text { Planned number: } 68 \\
\text { Condition/context: Mild } \\
\text { or greater elevation on } \\
\text { screening measures of } \\
\text { anxiety, depression } \\
\text { and/or traumatic stress; } \\
\text { parent of a child } \\
\text { aged 6-13 }\end{array}$ & US, Florida \\
\hline Lin $X[27]$ & ClinicalTrials.gov & 9 July 2020 & 31 January 2022 & $\begin{array}{l}\text { Study protocol for a } \\
\text { randomized clinical trial }\end{array}$ & $\begin{array}{c}\text { Target group: Parents } \\
\text { Planned number: } 300 \\
\text { Condition/context: } \\
\text { Parent of a student in } \\
\text { primary and } \\
\text { secondary school }\end{array}$ & China, Beijing \\
\hline Miklósi M [28] & ISRCTN registry & 23 May 2020 & 15 December 2020 & $\begin{array}{l}\text { Study protocol for a } \\
\text { randomized } \\
\text { controlled trial }\end{array}$ & $\begin{array}{c}\text { Target group: Parents } \\
\text { Planned number: } 300 \\
\text { Condition/context: } \\
\text { Parental stress; parent of } \\
\text { a child aged <18 }\end{array}$ & Hungary \\
\hline Francis L [29] & ClinicalTrials.gov & 1 July 2020 & September 2021 & $\begin{array}{l}\text { Study protocol for a } \\
\text { pilot clinical trial }\end{array}$ & $\begin{array}{l}\text { Target group: Parents, } \\
\text { other caregivers } \\
\text { Planned number: } 270 \\
\text { Condition/context: } \\
\text { Family Child Care } \\
\text { Home (FCCH) } \\
\text { providers, parent of } \\
\text { child aged 3-6 served by } \\
\text { enrolled FCCH provider }\end{array}$ & US, Maryland \\
\hline
\end{tabular}

Table 3. Characteristics of interventions.

\begin{tabular}{|c|c|c|c|c|c|c|}
\hline First Author(s) & $\begin{array}{c}\text { Description of } \\
\text { Specific Measure(s) }\end{array}$ & Format & Mode of Delivery & Comparison Group & $\begin{array}{c}\text { Primary Outcome } \\
\text { Measures }\end{array}$ & $\begin{array}{l}\text { Follow-Up } \\
\text { (Baseline) }\end{array}$ \\
\hline Chen S [17] & $\begin{array}{l}\text { Solution Focused } \\
\text { Brief Therapy } \\
\text { (SFBT) }\end{array}$ & $\begin{array}{c}\text { Sessions: } 2-4 \\
\text { Duration: } 2 \text { weeks }\end{array}$ & $\begin{array}{l}\text { Online platforms, } \\
\text { such as Zoom }\end{array}$ & $\begin{array}{l}2-4 \text { sessions of } \\
\text { counselling service }\end{array}$ & $\begin{array}{c}\text { Anxiety (Generalised } \\
\text { Anxiety Disorder-7, } \\
\text { State-Trait } \\
\text { Anxiety-Inventory) }\end{array}$ & 2 weeks, 1 month \\
\hline Zheng Y [19] & $\begin{array}{c}\text { Recess and Exercise } \\
\text { Advocate Program } \\
\text { (REAP, } \\
\text { llive-streaming } \\
\text { stay-at-home } \\
\text { workouts) }\end{array}$ & $\begin{array}{l}\text { Sessions: NR } \\
\text { Duration: NR }\end{array}$ & Mobile application & $\begin{array}{l}\text { Online health } \\
\text { information }+ \\
\text { stay-at-home } \\
\text { workout videos }\end{array}$ & $\begin{array}{c}\text { Anxiety (Spence } \\
\text { Children's Anxiety } \\
\text { Scale) }\end{array}$ & 2 weeks \\
\hline
\end{tabular}


Table 3. Cont

\begin{tabular}{|c|c|c|c|c|c|c|}
\hline First Author(s) & $\begin{array}{c}\text { Description of } \\
\text { Specific Measure(s) }\end{array}$ & Format & Mode of Delivery & Comparison Group & $\begin{array}{c}\text { Primary Outcome } \\
\text { Measures }\end{array}$ & $\begin{array}{l}\text { Follow-Up } \\
\text { (Baseline) }\end{array}$ \\
\hline $\begin{array}{l}\text { Tymofiyeva } \\
\text { O [20] }\end{array}$ & $\begin{array}{c}\text { Training for } \\
\text { Awareness, } \\
\text { Resilience, and } \\
\text { Action (TARA, } \\
\text { meditation training) }\end{array}$ & $\begin{array}{c}\text { Sessions: NR } \\
\text { Duration: } 12 \text { weeks }\end{array}$ & $\begin{array}{l}\text { Partially over the } \\
\text { online platform } \\
\text { Zoom in a group of } \\
12 \text { adolescents }\end{array}$ & $\begin{array}{l}\text { Waitlist control } \\
\text { group }(9 \\
\text { adolescents })\end{array}$ & $\begin{array}{l}\text { Emotional problems } \\
\text { (Strengths and } \\
\text { Difficulties } \\
\text { Questionnaire Items) }\end{array}$ & 12 weeks \\
\hline Pavarini G [22] & $\begin{array}{l}\text { Peer support } \\
\text { training }\end{array}$ & $\begin{array}{l}\text { Sessions: } 5(\mathrm{à} 4 \mathrm{~h}) \\
\text { Duration: } 5 \text { days }\end{array}$ & Online & $\begin{array}{l}\text { Waitlist control } \\
\text { group }\end{array}$ & $\begin{array}{l}\text { Motivation to provide } \\
\text { peer support, perceived } \\
\text { support giving skills, } \\
\text { frequency of support } \\
\text { provided (Adolescent } \\
\text { Social Connection and } \\
\text { Coping During COVID } \\
\text { Scale Items) } \\
\text { Compassion towards } \\
\text { others (Compassionate } \\
\text { Engagement and Action } \\
\text { Scale-Compassion for } \\
\text { Others Scale) } \\
\text { Connectedness to peers } \\
\text { (Inclusion of Other in the } \\
\text { Self Scale) }\end{array}$ & $\begin{array}{l}1 \text { week (all) } \\
2,3,4 \text { weeks } \\
\text { (intervention } \\
\quad \text { arm) }\end{array}$ \\
\hline Green S [23] & $\begin{array}{c}\text { Cognitive } \\
\text { Behavioral Group } \\
\text { Therapy (CBGT) }\end{array}$ & $\begin{array}{l}\text { Sessions: } 8(\mathrm{a} 2 \mathrm{~h}) \\
\text { Duration } 8 \text { weeks }\end{array}$ & Groups of 6 people & / & $\begin{array}{l}\text { Anxiety (State-Trait } \\
\text { Inventory of Cognitive } \\
\text { and Somatic Anxiety) }\end{array}$ & $\begin{array}{l}8 \text { weeks, } \\
3 \text { months }\end{array}$ \\
\hline Huang HF [24] & $\begin{array}{c}\text { Internet-based } \\
\text { Cognitive Behavior } \\
\text { Therapy (iCBT) } \\
\text { (text- or } \\
\text { video-based } \\
\text { self-help resources) }\end{array}$ & $\begin{array}{c}\text { Sessions: } 7 \\
\text { Duration: } 6 \text { weeks }\end{array}$ & Mobile application & Routine treatment & $\begin{array}{c}\text { Perinatal depression } \\
\text { (Edinburgh Postnatal } \\
\text { Depression Scale) }\end{array}$ & $\begin{array}{c}\text { 3. trimester }+ \\
6 \text { weeks, } 3,6,9 \\
\text { months, } 1 \text { year } \\
\text { postpartum }\end{array}$ \\
\hline Monga S [25] & $\begin{array}{c}\text { Virtual-Care } \\
\text { Cognitive } \\
\text { Behavioral Therapy } \\
\text { (VC-CBT) }\end{array}$ & $\begin{array}{l}\text { Sessions: } 12 \text { (à } 1 \mathrm{~h}) \\
\text { Duration: } \\
\text { 12-16 weeks }\end{array}$ & $\begin{array}{l}\text { Online platform } \\
\text { Zoom }\end{array}$ & / & $\begin{array}{c}\text { Family impact } \\
\text { (CoRonavIruS Health } \\
\text { Impact Survey) } \\
\text { Efficacy of Virtual-Care } \\
\text { CBT Intervention (Child } \\
\text { and parent-report Screen } \\
\text { for Child Anxiety } \\
\text { Related Disorders) } \\
\text { Clinician virtual-care } \\
\text { experience (Clinician } \\
\text { Virtual-Care } \\
\text { Experience Survey) }\end{array}$ & $12-16$ weeks \\
\hline $\begin{array}{c}\text { Ehrenreich-May J } \\
{[26]}\end{array}$ & $\begin{array}{l}\text { Unified Protocol for } \\
\text { COVID-19 } \\
\text { Parenting Stress } \\
\text { (UP-COVID) } \\
\text { intervention } \\
\text { (cognitive } \\
\text { behavioral therapy) }\end{array}$ & $\begin{array}{l}\text { Sessions: } 4 \text { (à } \\
\text { 30-90 min) } \\
\text { Duration: NR }\end{array}$ & Group therapy & $\begin{array}{l}\text { Delayed condition } \\
\text { group (self-help } \\
\text { guide + UP-COVID } \\
\text { intervention after } \\
6 \text { weeks) }\end{array}$ & $\begin{array}{c}\text { Anxiety (Overall } \\
\text { Anxiety Severity and } \\
\text { Impairment Scale) } \\
\text { Depression (Overall } \\
\text { Depression Severity and } \\
\text { Impairment Scale) } \\
\text { PTSD (Post-traumatic } \\
\text { Stress Disorder Checklist } \\
\text { for DSM-5) }\end{array}$ & 6,12 weeks \\
\hline Lin $X[27]$ & $\begin{array}{l}\text { 1. Cognitive and } \\
\text { behavioral } \\
\text { parent-child } \\
\text { relationship } \\
\text { intervention } \\
\text { 2. Problem-solving } \\
\text { and couple } \\
\text { relationship } \\
\text { improvement } \\
\text { intervention }\end{array}$ & $\begin{array}{l}\text { 1. Sessions: } 5 \text { (à } 2 \text { h) } \\
\text { 2. Sessions: } 4 \text { (à } 2 \text { h) } \\
\text { Duration: NR }\end{array}$ & $\begin{array}{l}\text { Online group } \\
\text { therapy }\end{array}$ & / & $\begin{array}{c}\text { Parent-child conflict } \\
\text { (Conflict subscale of the } \\
\text { Child-Parent } \\
\text { Relationship Scale) } \\
\text { Parent-child } \\
\text { communication (Family } \\
\text { Communication Scale) } \\
\text { Parent-child } \\
\text { relationship } \\
\text { (Child-Parent } \\
\text { Relationship Scale) } \\
\text { Couple relationship } \\
\text { quality (Quality of } \\
\text { Marriage Index) } \\
\text { Marital stability } \\
\text { (Stability of Marriage } \\
\text { Scale-Short Form) }\end{array}$ & 2 weeks \\
\hline
\end{tabular}


Table 3. Cont.

\begin{tabular}{|c|c|c|c|c|c|c|}
\hline First Author(s) & $\begin{array}{c}\text { Description of } \\
\text { Specific Measure(s) }\end{array}$ & Format & Mode of Delivery & Comparison Group & $\begin{array}{c}\text { Primary Outcome } \\
\text { Measures }\end{array}$ & $\begin{array}{c}\text { Follow-Up } \\
\text { (Baseline) }\end{array}$ \\
\hline Miklósi M [28] & $\begin{array}{l}\text { Online parenting } \\
\text { training programme } \\
\text { 1. Training } \\
\text { materials (text- or } \\
\text { video-based) } \\
\text { 2. Training } \\
\text { materials + online } \\
\text { forum } \\
\text { 3. Training } \\
\text { materials + online } \\
\text { forum + therapist } \\
\text { feedback }\end{array}$ & $\begin{array}{l}\text { Sessions: } 15-30-m i n \\
\text { daily activity } \\
\text { Duration: } 2 \text { weeks }\end{array}$ & Online platform & / & $\begin{array}{c}\text { Perceived stress } \\
\text { (Perceived Stress Scale, } \\
\text { four-item version) } \\
\text { Psychological well-being } \\
\text { (WHO Well-being Index) } \\
\text { Parenting stress } \\
\text { (Parental Stress Scale, } \\
\text { shortened) } \\
\text { Parental competence } \\
\text { (Parental Sense of } \\
\text { Competence Scale) }\end{array}$ & $\begin{array}{l}2 \text { weeks, } 1 \\
3 \text { months }\end{array}$ \\
\hline Francis L [29] & $\begin{array}{c}\text { Tele-wellness } \\
\text { supported digital } \\
\text { toolkit (parenting } \\
\text { support + self-care } \\
\text { resources/digital } \\
\text { learning games for } \\
\text { children) }\end{array}$ & $\begin{array}{c}\text { Sessions: daily/3 } \\
\text { times per week (à } \\
30 \text { min) } \\
\text { Duration: NR }\end{array}$ & Mobile application & / & $\begin{array}{l}\text { Perceived level of stress } \\
\text { (Perceived Stress } \\
\text { Scale 10) } \\
\text { Perceived level of } \\
\text { informational support } \\
\text { (Patient-Reported } \\
\text { Outcomes Measurement } \\
\text { Information System) } \\
\text { Awareness of the } \\
\text { Maryland early } \\
\text { childhood family } \\
\text { engagement framework } \\
\text { and toolkit (Survey } \\
\text { question) } \\
\text { Social, emotional, and } \\
\text { behavior functioning in } \\
\text { children (Social } \\
\text { Competence and } \\
\text { Behavior Evaluation for } \\
\text { Children-Short Form) }\end{array}$ & 15 weeks \\
\hline
\end{tabular}

We found seven papers that describe system-based interventions targeted at parents, caregivers, and families. Two trial protocols present behavioral interventions with a special focus on pregnant women and mothers of infants, addressing perinatal anxiety and/or depression during the COVID-19 pandemic.

The planned study by Green [23] aims at assessing the effectiveness of an augmented version of a Cognitive Behavioral Group Therapy (CBGT). Enrolled women will undergo treatment that is based on cognitive and behavioral strategies for treating perinatal/postpartum anxiety and additionally addresses critical COVID-19-related worries and impacts. Huang [24] plans to evaluate the effect of an internet-based Cognitive Behavior intervention (iCBT) which comprises mental health education, cognitive restructuring, problem-solving, behavior reinforcement, and relapse prevention strategies and techniques, tailored to a perinatal population. Participants will receive weekly text- or video-based self-help resources via a perinatal mental healthcare app. After studying each course material, the women will be asked to give digital feedback to the therapist.

Three further clinical trial protocols plan to apply cognitive and behavioral strategies to positively impact COVID-19-specific family distress, anxiety, depression or the parentchild and couple relationship: the planned trial by Monga [25] aims at assessing an adapted Virtual-Care Cognitive Behavioral Therapy (VC-CBT) delivered by a therapist. Parents will accompany their children into the first and last therapy sessions and join at the end of each session for a review of newly acquired skills and completed exposure tasks. The purpose of another research study by Ehrenreich-May [26] is to evaluate the group cognitive behavioral therapy named Unified Protocol for COVID-19 Parenting Stress (UP-COVID). Lin [27] plans to provide online psychological interventions for parents. Participants in a parent-child relationship intervention group will receive cognitive and behavioral group therapy sessions including mindfulness and emotion regulation training to improve parent-child communication. Parents assigned to a couple relationship intervention group will participate in group therapy sessions that will focus on problem-solving and marital relationship improvement. 
The last two study protocols focus on digital interventions aiming at reducing caregivers' level of stress and improving the social, emotional and behavioral well-being of parents and children during the pandemic: Miklósi [28] plans to examine the effect of an internet-based parenting training and to determine the optimal program structure. The program will provide short psychoeducation videos and written materials focusing on parents' and children's stress. Worksheets, quizzes, and feedback forms will be involved to increase the participants' engagement with the training program. Parents will have flexible access to the online platform. In a protocol for a pilot clinical trial, Francis [29] describes a tele-wellness supported digital toolkit through which parents and other caregivers will receive daily parenting support and self-care resources. Parents will additionally be asked to provide their child access to digital learning games in the app.

\section{Discussion}

With this systematic review, we identified interventions for children, their families and / or caregivers that may mitigate psychosocial effects caused by the COVID-19 pandemic or similar epidemics in children. No completed studies on the subject could be identified. However, we included 11 study protocols that aim at assessing interventions developed in response to the ongoing COVID-19 pandemic. The included child-based interventions mainly address anxiety and emotional problems in the targeted individuals, whereas the system-oriented approaches assess plan direct and indirect outcomes, such as stress, depression or self-efficacy on one hand, and family conflict, communication, and relationships and child well-being on the other hand. The studies were planned and will be conducted in China, the US, Canada, UK, and Hungary. Why there were no previous studies on SARS, MERS, or H1N1 influenza outbreaks might be explained by a lack of awareness of and attention paid to the adverse impacts on children, possibly due to the relatively smaller extent, shorter duration, and lower intensity of enforced measures to contain the disease spread during these past outbreaks.

\subsection{Population}

The included protocols for planned intervention studies not only targeted children directly, but also parents and caregivers of children. All parent-oriented interventions use a system-based approach by which children's psychosocial well-being is to be positively influenced by enhancing the caregivers' emotional stability and parenting competence. Since rising levels of stress associated with emotional disturbance and irritability in parents are related to reduced closeness of family relationships and higher incidence of harsh or punitive parenting [30]. Insecure parent-child attachments, in turn, are associated with higher risk of children developing internalizing and externalizing behavior problems that may persist into later life [31,32]. A high-risk group are pregnant women, particularly vulnerable to develop anxiety and depressive symptoms that can cause psychological distress and adversely affect the early healthy growth and development of their children [33]. Parenting practices, coping mechanisms and family environment have been shown to affect children's mental health throughout and well after disasters [34]. Parents therefore represent an important target group for intervention approaches during and after emergency situations, not only for the sake of their own but also their entire family's psychological well-being.

\subsection{Intervention Types}

The most widely recognized psychotherapeutic technique in the context of reducing anxiety and affective disorders is Cognitive Behavioral Therapy (CBT). CBT, as applied in several included trial protocols (23-26), has shown to be effective in individual, group, and family formats. Although mostly delivered face to face, it can also be carried out via virtual teleconferences [35]. The efficacy of the latter in the reduction of symptoms of anxiety and depression in pediatric populations was recently reviewed, showing a medium effect size of internet-based CBT compared to waitlist control groups [36]. A web-based self-help approach of trauma-focused CBT, designed specifically to help children and parents recover 
from traumatic life events and improve disaster-related PTSD symptoms, performed well in another efficacy study [37]. Evidence-based, scalable virtual-care CBT programs targeted at youth and/or parents might therefore be of significant value during pandemic crises as well as during post-pandemic recovery periods.

In contrast to diagnostic, step-by-step therapeutic approaches, the SFBT treatment, as tested by Chen [17], encourages flexibility when incorporating underlying techniques in order to meet each client's individual needs and achieve sustainable changes within a few therapy sessions. Empirical evidence shows its effectiveness in addressing internal psychological problems, such as anxiety and/or depression, across diverse populations and various settings, such as schools [38]. Due to its high level of adaptability, it might be a promising therapeutic approach to overcome mental health disorders in quickly evolving and unpredictable pandemic situations.

TARA, as proposed by Tymofiyeva [20], builds on elements of time-sensitivity and the creation of a platform for attention and behavioral motivation [21]. The mindfulness intervention has demonstrated maintained efficacy in reducing anxiety and depressive symptoms in adolescents [39]. As other types of therapy showed comparable symptom and behavior outcomes if delivered remotely, TARA might be another promising therapeutic approach to apply during pandemic-related quarantine measures.

Some study protocols [27-29] consider prevention-based psychological approaches to reduce family stress and enhance emotional well-being as well as relationship and parenting skills. Self-directed (SD) parenting interventions with varying levels of support through a therapist provide caregivers with support and self-care materials to acquire positive behavioral strategies. In a recent empirical research, parental psychological flexibility showed to be robustly linked to family functioning in the midst of a pandemic. Accordingly, parental inflexibility was predictive of greater COVID-19-related stress, leading to worsened family cohesion, higher family discord and reduced child and parent wellbeing [40]. Findings from another study emphasize the significant role of parenting stress in constructive parenting behavior and parent-child relationships during COVID-19 [30]. SD interventions have delivered supportive outcomes of decreased negative child behaviors, improved parenting behaviors and family interactions along with reduced parental stress [41]. Telehealth formats of the SD intervention Parent-Child Interaction Therapy (PCIT) [42] and Triple P [43] were found to be comparably effective. Online parent support programs therefore present potentially valuable public health approaches for helping families to overcome challenges of a large-scale crisis such as the COVID-19 pandemic.

The intervention approach proposed by Zheng [19] is physical activity-based. Physical activity (PA) is an adaptive coping strategy that can help to reduce anxiety levels and depressive symptoms [44,45]. For children, PA is closely linked to school hours and related activities such as active travel to school or organized sports [46]. As a consequence of school closures and stay-at-home orders in the wake of the COVID-19 pandemic, opportunities for children to meet movement behavior guidelines are compromised. First studies on the topic report on substantially decreased PA levels and increased screen time in youth since the initial outbreak [47-49]. Interventions such as the REAP may be promising approaches to encourage exercise uptake at home in order to counteract the lack of PA related to public health restrictions on the one hand, while reducing psychological symptoms, such as stress and anxiety, and improving well-being on the other hand.

Social and community support are generally discussed as critical protective factors for resilience and mental health in children [50]. Involuntary social isolation as a consequence of pandemic control measures is likely to result in higher levels of loneliness which in turn are associated with the onset of mental disorders [51]. Online peer support as proposed by Pavarini [22] can help young people to connect, provide and seek emotional and informational support as well as to share experiences and thereby reduce negative impacts of otherwise disrupted social networks. The effectiveness of online peer-to-peer interaction as a stand-alone intervention in improving mental health in youth has yet to be evaluated [52]. 


\subsection{Intervention Delivery}

The majority of the planned interventions will be provided over telecommunication platforms accessible via the Internet, such as Zoom. Some approaches will make use of digital mobile health (mHealth) applications. During pandemics with measures to contain transmission, digital solutions present promising ways with increasing impact to bridge the social distance and deliver health services to populations with eHealth literacy, i.e., the young, that may at the same time be vulnerable and underserved. An evolving evidence base supports the feasibility, acceptability and efficacy of digital mental health interventions in children and adolescents in non-crisis times [53-56]. The opportunities in eHealth or mHealth interventions lie in a simplified and low-threshold access, scalability and economic benefits [57]. However, their implementation in times of pandemic restrictions can pose challenges. Perrin and colleagues [58] outline situations where chaotic home environments and limited privacy during COVID-19 self-isolation and quarantine measures complicated telepsychology sessions. Other challenges discussed in the literature were related to the technology itself, as use and success of virtual prevention and treatment require suitable electronic devices and reliable home internet connection. Some authors expressed concerns regarding disparities in access to digital resources due to, for example, rural settings or socioeconomic status, urging for universal, equal and secure provision of telehealth services in order to unfold their potential to contribute to sustainable health equity in the long term $[59,60]$. Overall, the pandemic is a potential driver for digitalization in healthcare delivery.

\subsection{Funding}

Universities or university associated foundations or hospitals were named as sponsors for most of the studies. The study by Green et al. [23] was sponsored by a health care foundation named St. Joseph's Healthcare Hamilton. For only one study by Pavarini et al. [22], it was explicitly mentioned that it was funded by an Urgent Response Fund, the "Economic, Social, Cultural and Environmental Impacts of COVID-19: Urgent Response Fund" by the Oxford University/Torch, UK. This study additionally drew on the expertise and resources of YouthEra, a non-profit organization with experience in youth empowerment and peer support training programs, and the McPin Foundation with the aim to transform mental health research. Thus, after 9 months from the onset of the pandemic, only one study was funded based on an explicitly mentioned funding structure for COVID-19 projects. On the other hand, no studies were funded by ministries or government research organizations which can be interpreted as a gap of early response funding resources in the field of childhood mental health projects in the context of pandemics.

\subsection{Gaps}

All study protocols present interventions that aim at behavior modification. There was little material on interventions that operate on a situational level. Roca and colleagues [61] present virtual evidence-based actions applied in schools in Spain during enforced closure periods serving as open doors to a safe environment for interactions with the aim of preventing child abuse. The strategy included, for example, dimensions of online dialogic workspaces and dialogic gatherings with students. The action plans were derived from school-based abuse prevention programs that have previously shown to be effective in providing knowledge and skills for children to understand concepts of abuse and in reducing the risk of violence. The authors point out on further potential actions inspired by existing school-based interventions. The evaluation of such as well as other structural prevention or promotion approaches in the current pandemic context is required in order to assess their efficacy throughout large-scale crises.

We found a lack of approaches that specifically address maltreatment and abuse of children. High levels of familial stress can result in impulsive or even aggressive behavior responses [62]. Physical isolation is likely to exacerbate already strained situations [46]. Several countries have reported on increased violence against women and children associated 
with the implementation of COVID-19 emergency measures [63]. In a recent perspective paper, Emezue [64] reviews evolving digital solutions at both micro- and macrolevel to mitigate domestic violence in the context of the current pandemic. The research highlights some web- and mobile-based interventions that have been proven effective in preventing violence and increasing safety for several survivor cohorts in pre-pandemic times and could also be adopted to the current crisis situation. In view of the significant violence risk exposure of children during home confinement, interventions against domestic violence need to be adapted and scaled up.

\subsection{Strengths and Limitations}

It is noteworthy that although we performed a very extensive review covering established health and psychological databases, COVID-19 databases as well as trial registries and yielded 6657 records, we were only able to include 11 study protocols and no completed study. The fact that reviews, even performed to a high scientific standard, result in no or few completed studies included is well described and acknowledged by organizations such as the Joanna Briggs Institute or Cochrane $[65,66]$. This may happen in areas of limited evidence, new topics, or very specific questions asked. To tackle this challenge in a pandemic, we set the frame very broad with a wide definition of the population, interventions, outcomes, study designs, and related pandemic settings. However, the fact that we only found 11 study protocols under these circumstances is a result per se. From our point of view, it reveals a knowledge gap in a field that will be of high relevance in the near future and pandemic aftermath. In addition, although we cannot base our strategies on effects of interventions, the benefit of this review is to identify, discuss and highlight the range of potentially promising strategies that could be used and upscaled in the future and to frame and set the research agenda in the field.

Some further limitations have to be put into account. Due to the fast-paced science related to COVID-19, there is a high publication frequency that makes this work a snapshot of the current but rapidly changing knowledge base. Moreover, a snapshot of what type of interventions researchers planned in the first semester of the pandemic which might not be the same strategy as in later stages of the pandemic. This early phase was also the reason some $(n=19)$ full texts could not yet be retrieved at the time of data extraction. Although the fact that all manuscripts report only study protocols, but not on completed studies, leaves the question unanswered whether the described approaches will also be effective or not.

Especially in the grey literature, we might have additionally missed interesting interventions and approaches not described in scientific publications, such as digital solutions in the format of mobile applications and others.

\section{Conclusions}

Since we expect a high burden of mental health impacts during and in the aftermath of the COVID-19 pandemic among the young, there is likely to be a high demand for pragmatic mental health management concepts and interventions. To address this need, different approaches would be helpful: on the one hand, we may draw on existing evidence generated during non-pandemic situations and adapt materials and approaches, such as information resources and mHealth tools, to the COVID-19 pandemic and future large-scale crises contexts. On the other hand, we have very specific issues to address such as home confinement settings, disruption of education and opportunities for socialization, absence of structured days for a long duration, boredom and lack of physical, extracurricular, and outdoors activities. Because of these reasons, we would need specific and well-developed interventions targeting psychosocial effects on children in the context of the COVID-19 pandemic. At the same time, intervention programs that increase exercise, education, and socialization could include psychosocial outcomes as secondary objectives to enrich the knowledge in the field. Early financial support programs should integrate mental health prevention as part of the pandemic response. Furthermore, the effectiveness of 
these interventions should be evaluated carefully, to allow for evidence-based decisions in future pandemics on how to mitigate the impact of these crises on the mental health status of children.

Author Contributions: K.B., C.J.-S., M.C. and A.M. drafted the study protocol with the search strategy that was revised by K.B., C.J.-S., M.C., A.M. and S.V. performed the title and abstract screening. K.B., C.J.-S., M.C. and S.V. performed the full text screening. K.B. extracted data from included studies checked by C.J.-S., K.B. drafted the manuscript under the supervision of C.J.-S., M.C., A.M. and S.V. who revised and corrected the first versions of the manuscript. All authors (K.B., C.J.-S., M.C., A.M., S.V., E.R., A.M.K. and K.L.) read, revised, and approved the final manuscript. All authors have read and agreed to the published version of the manuscript.

Funding: The author(s) received no external financial support for the research, authorship, and/or publication of this article. For the acquisition of full texts that were not available online, the first author received financial support from the program for student research funding at LMU Munich, Lehre@LMU.

Institutional Review Board Statement: Not applicable.

Informed Consent Statement: Not applicable.

Data Availability Statement: All data generated or analyzed during this study are included in this published article.

Acknowledgments: We thank information specialist Irma Klerings (I.K.) for having reviewed and advised on our search strategy and Saskia Lindner (S.L.) for reviewing our data extraction form of the selected studies.

Conflicts of Interest: The authors declare no conflict of interest.

\section{List of Abbreviations}

$\begin{array}{ll}\text { CBT } & \text { Cognitive Behavioral Therapy } \\ \text { MERS } & \text { Middle East respiratory syndrome } \\ \text { PA } & \text { Physical activity } \\ \text { PTSD } & \text { Post-traumatic stress disorder } \\ \text { RCT } & \text { Randomized controlled trial } \\ \text { SARS } & \text { Severe acute respiratory syndrome } \\ \text { SD } & \text { Self-directed } \\ \text { SFBT } & \text { Solution Focused Brief Therapy } \\ \text { TARA } & \text { Training for Awareness Resilience and Action } \\ \text { UP-COVID } & \text { Unified Protocol for COVID-19 Parenting Stress }\end{array}$

\section{Appendix A. MEDLINE Search Strategy}

Database(s): Ovid MEDLINE(R) and Epub Ahead of Print, In-Process \& Other NonIndexed Citations, Daily and Versions(R) 1946-present

Results: 1319

Table A1. Search strategy

\begin{tabular}{|c|c|}
\hline \# & Searches \\
\hline & $\begin{array}{l}\text { exp coronavirus / } \\
\text { exp coronavirus infections / } \\
\text { covid }{ }^{*} \cdot \mathrm{mp} \text {. } \\
\left.\left(\left(\text { corona }^{*} \text { or corono }{ }^{*}\right) \text { adj1 (virus }{ }^{*} \text { or viral }{ }^{*} \text { or virinae }{ }^{*}\right)\right) \cdot m p . \\
\left(\text { coronavirus }^{*} \text { or coronovirus }{ }^{*} \text { or coronavirinae }{ }^{*}\right) \cdot \mathrm{mp} . \\
\left(\text { wuhan }{ }^{*} \text { or hubei }{ }^{*} \text { or huanan).mp. }\right. \\
(2019-\text { ncov or } 2019 \text { ncov or ncov } 2019 \text { or ncov-2019).mp. } \\
(\text { covid-19 or covid19 or corvid-19 or corvid19).mp. }\end{array}$ \\
\hline
\end{tabular}


Table A1. Cont.

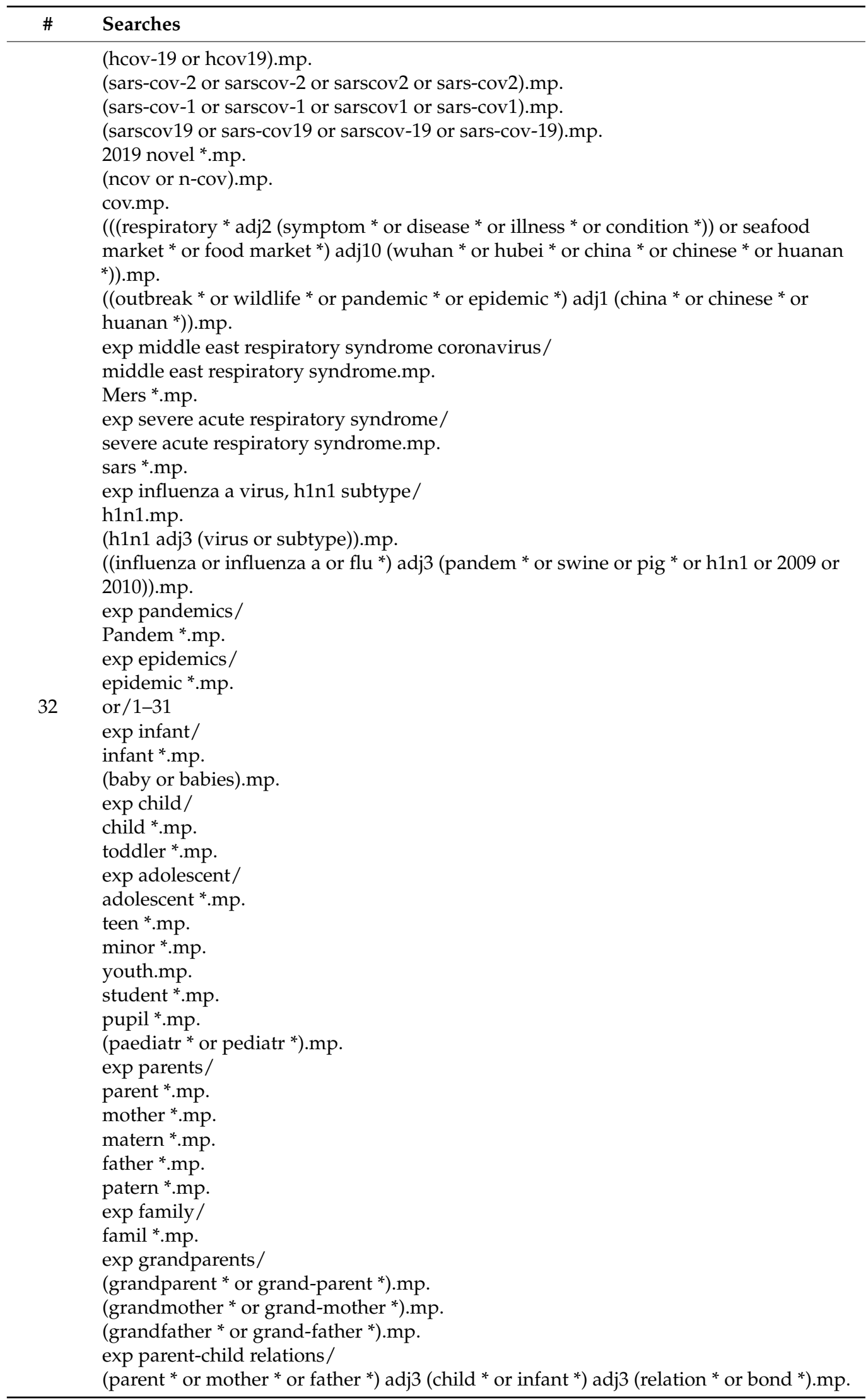


Table A1. Cont.

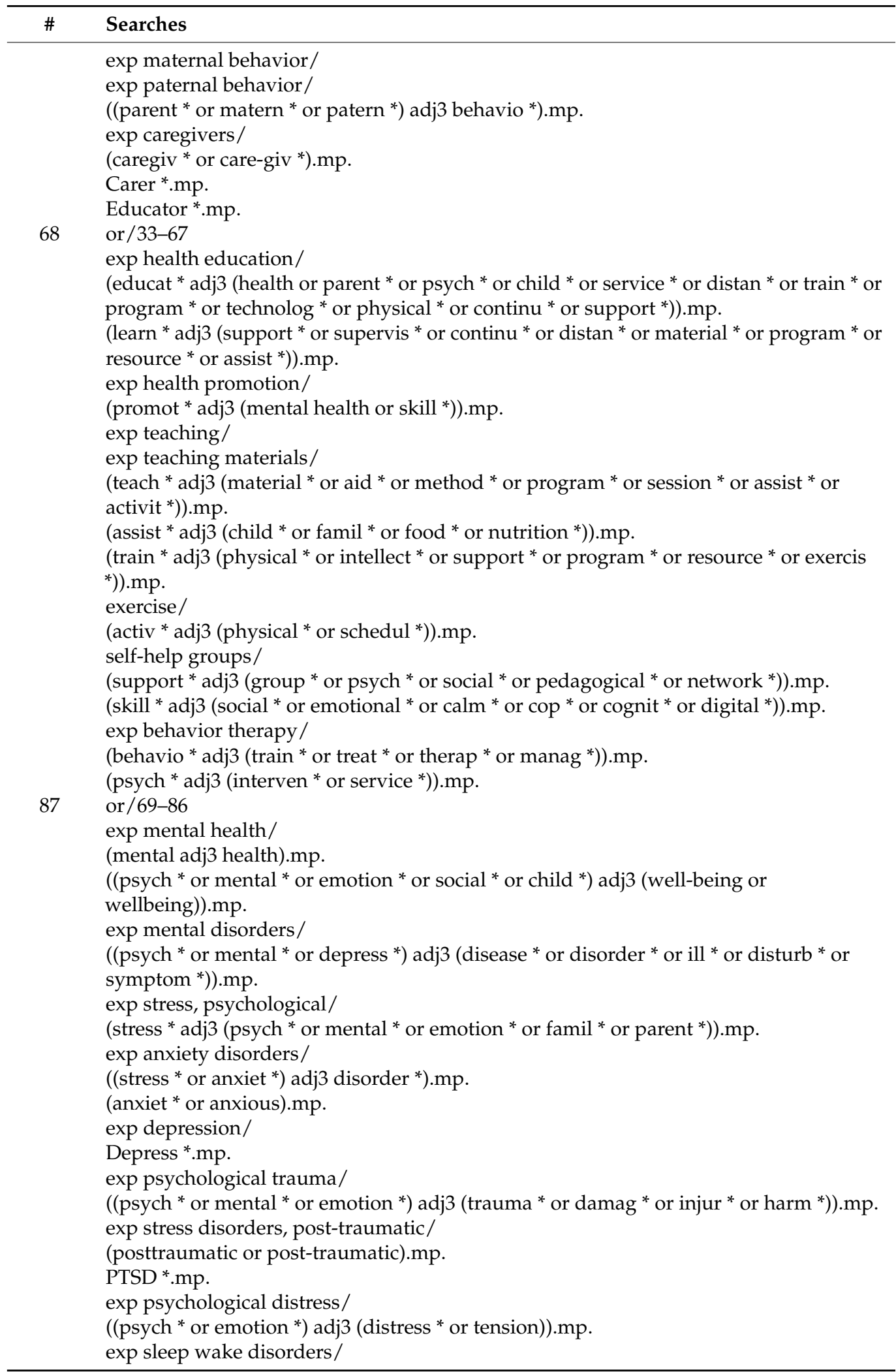


Table A1. Cont.

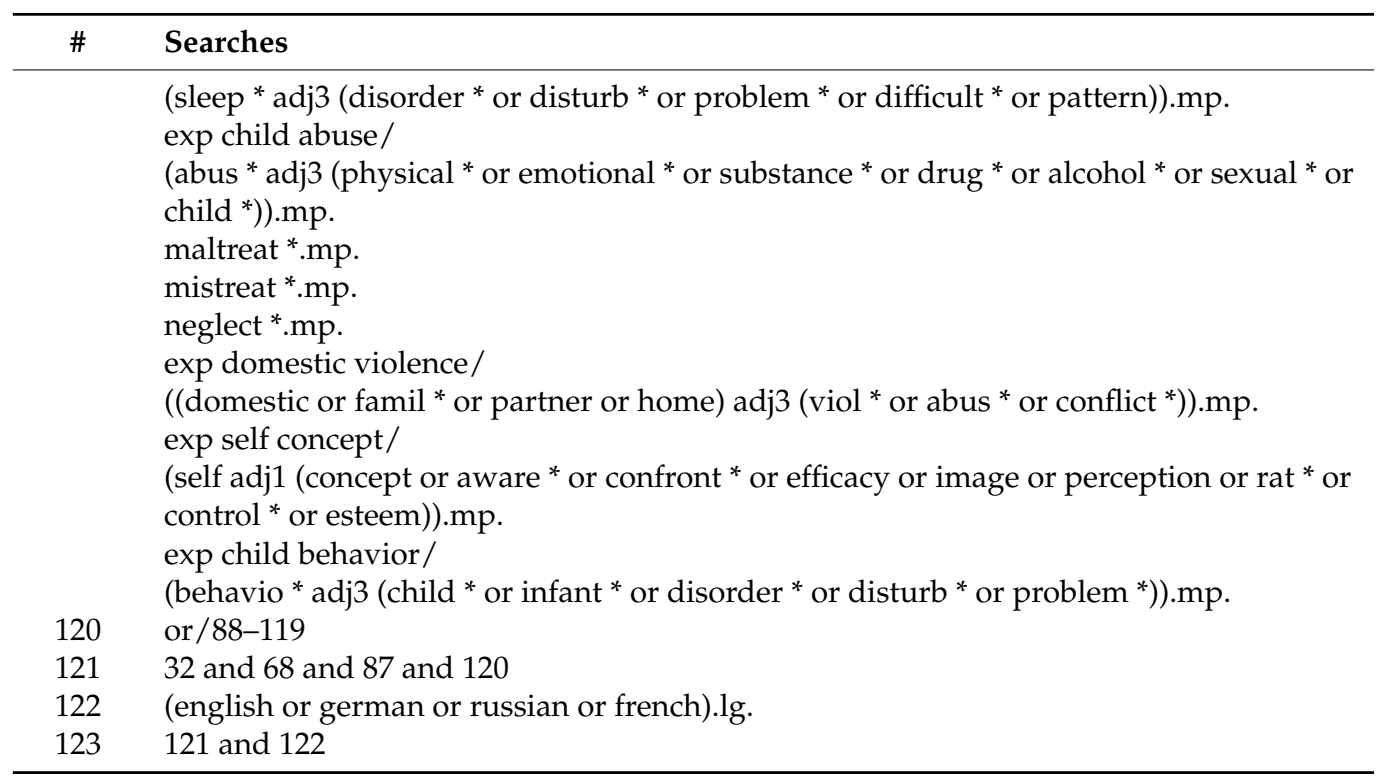

* Truncation.

\section{Appendix B. Embase Search Strategy}

Database(s): Ovid Embase 1974-present

Results: 1964

Table A2. Search strategy.

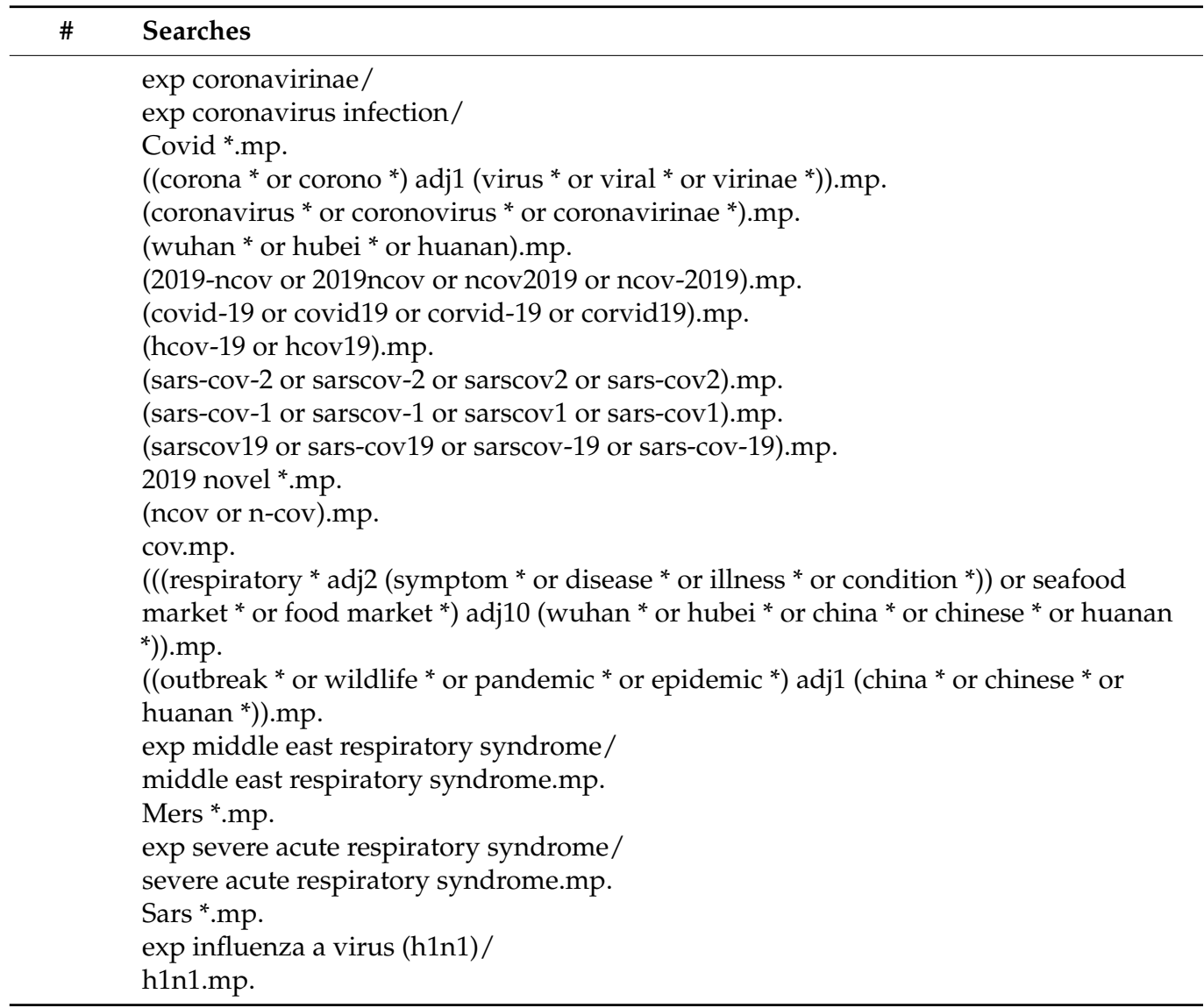


Table A2. Cont.

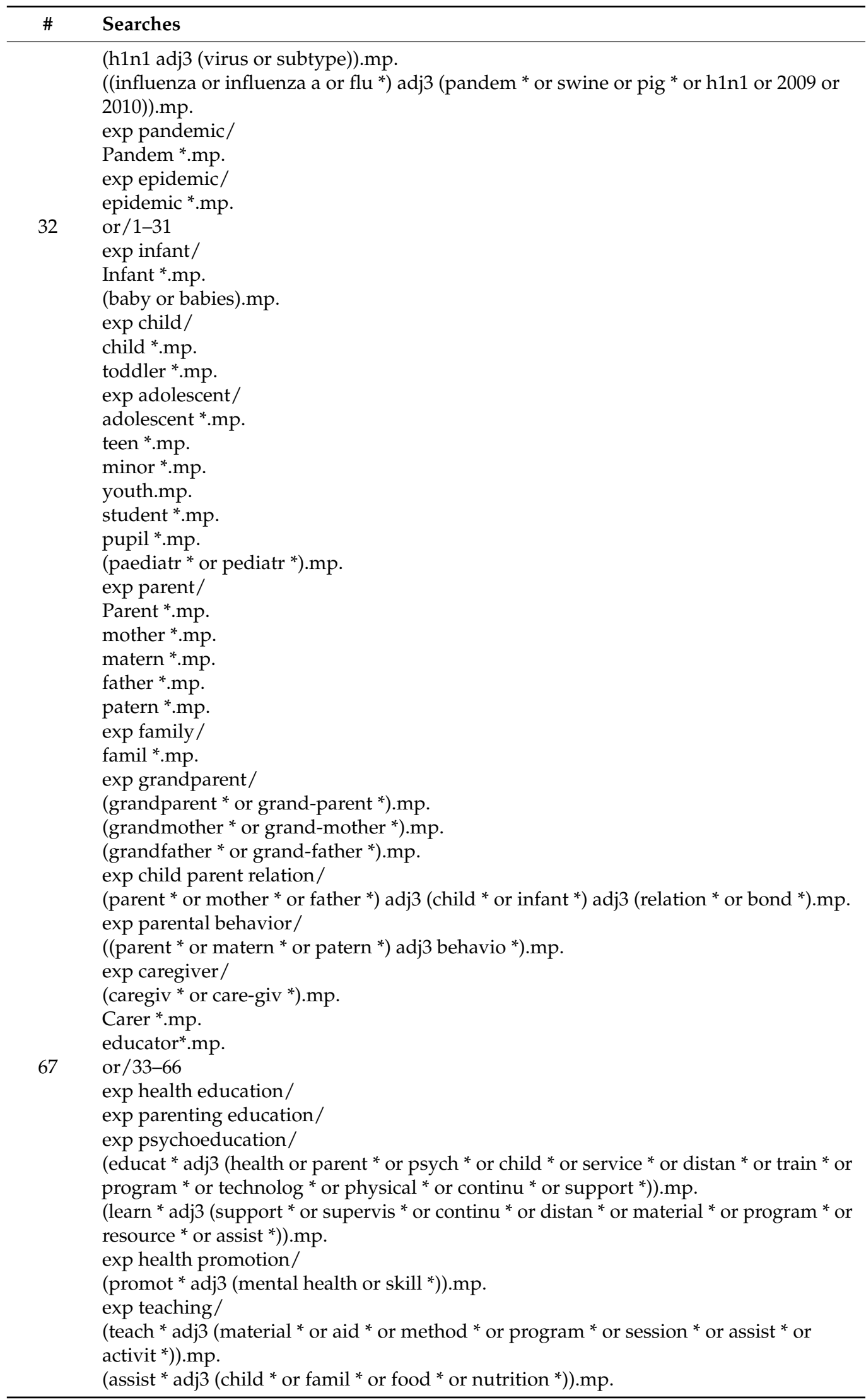


Table A2. Cont.

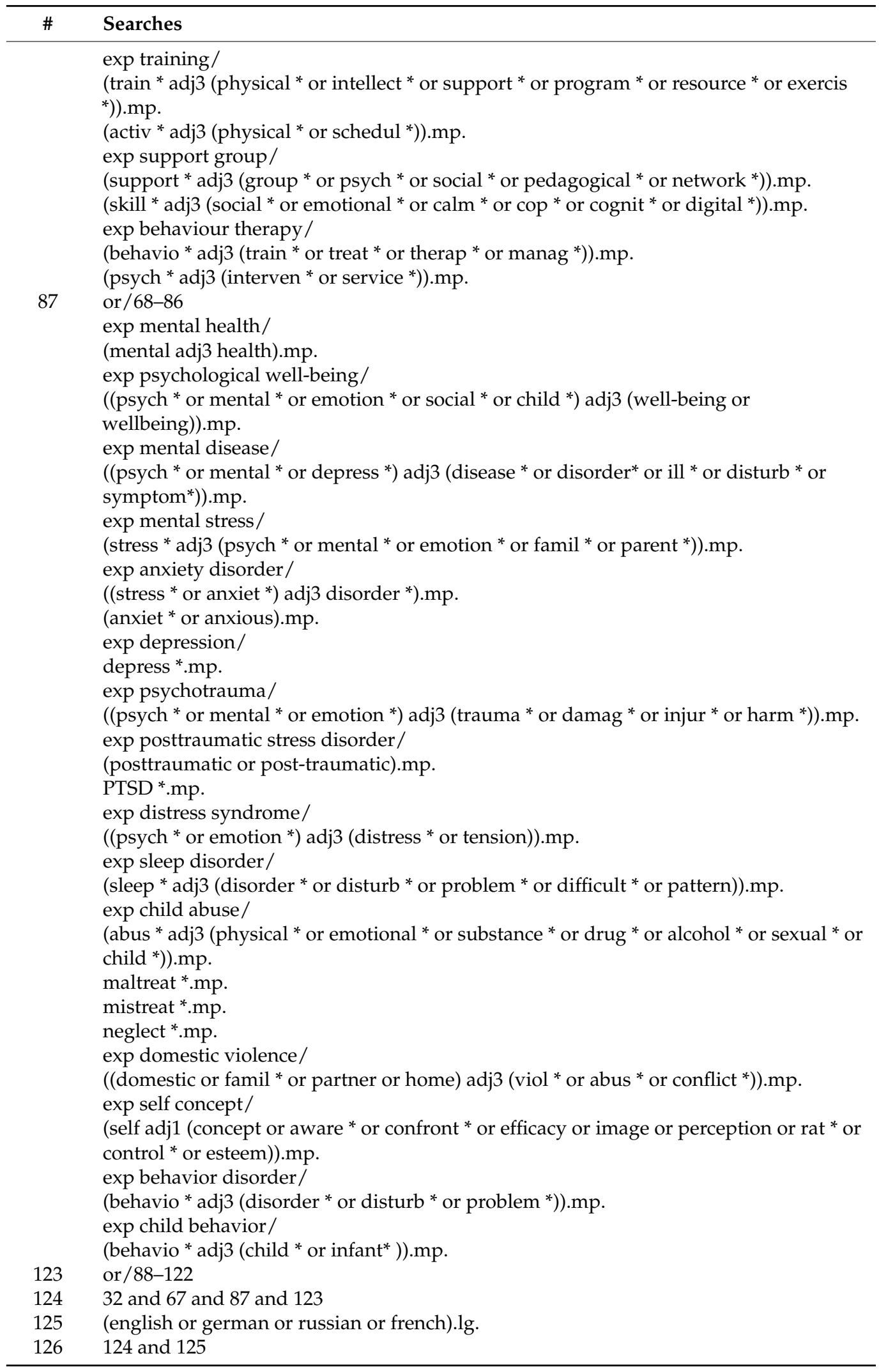

\section{Appendix C. PsycINFO Search Strategy}

Database(s): EbscoHost PsycINFO 1887-present

Results: 1272 
Table A3. Search strategy.

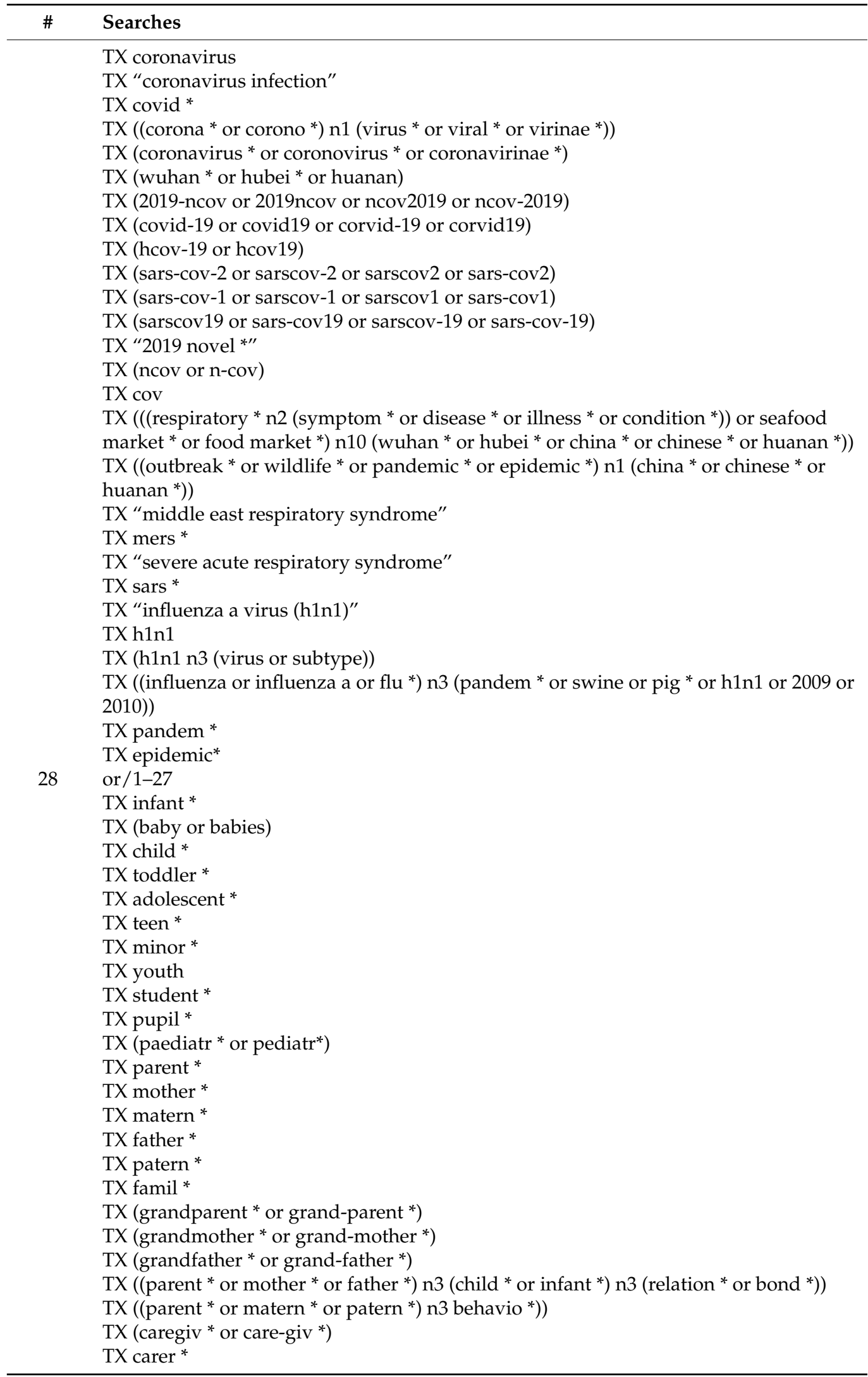


Table A3. Cont.

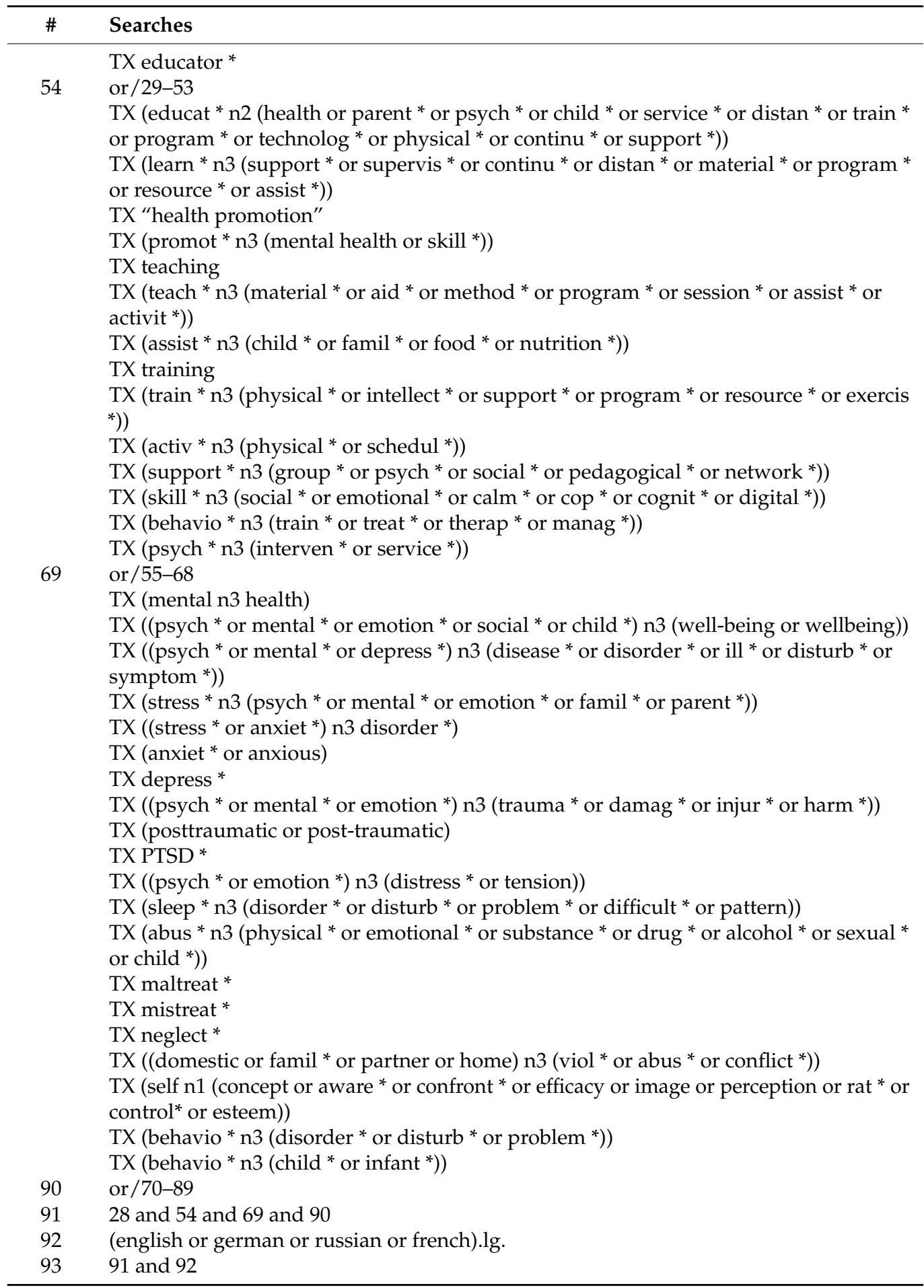

\section{Appendix D. CDC COVID-19 Research Articles Downloadable Database Search Strategy}

Database(s): CDC COVID-19 Research Articles Downloadable Database (https:// www.cdc.gov/library/researchguides/2019novelcoronavirus/researcharticles.html) 2020 Results: 2189 
Table A4. Search strategy.

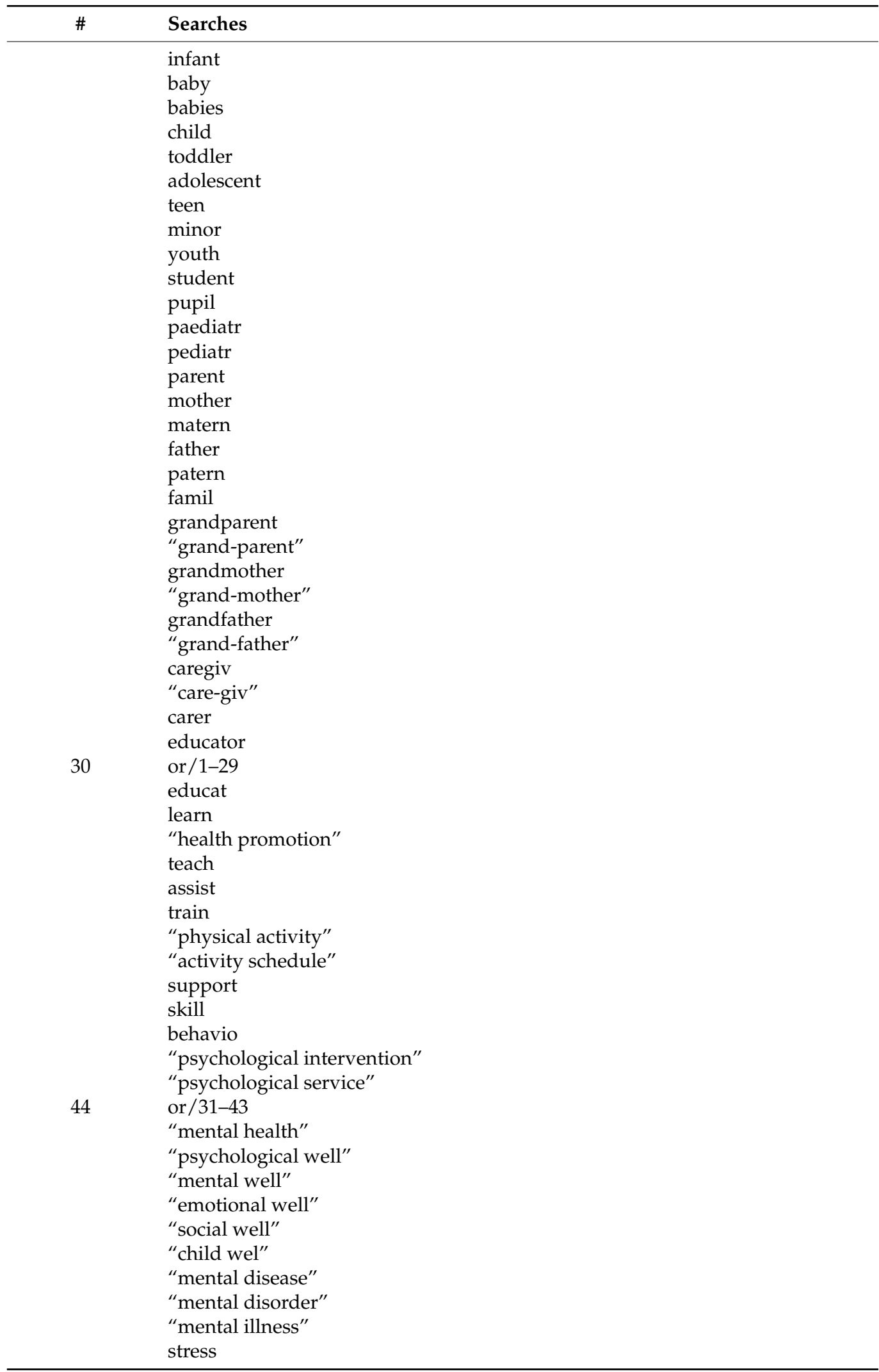


Table A4. Cont.

\begin{tabular}{ll}
\hline$\# \quad$ Searches \\
\hline anxiety \\
anxious \\
depress \\
trauma \\
PTSD \\
"psychological distress" \\
"sleep disorder" \\
abus \\
maltreat \\
mistreat \\
neglect \\
"domestic violence" \\
"family violence" \\
"family conflict" \\
"partner violence" \\
"self-concept" \\
"self-awareness" \\
"self-efficacy" \\
"self-perception" \\
"self-control" \\
"self-esteem" \\
or/45-75 \\
30 and 44 and 76 \\
77
\end{tabular}

\section{Appendix E. WHO COVID-19 Database Search Strategy}

Database(s): WHO COVID-19 Global literature on coronavirus disease (https: / / search. bvsalud.org/global-literature-on-novel-coronavirus-2019-ncov/) 2020

Results: 1011

Table A5. Search strategy.

\begin{tabular}{|c|c|}
\hline$\#$ & Searches \\
\hline & 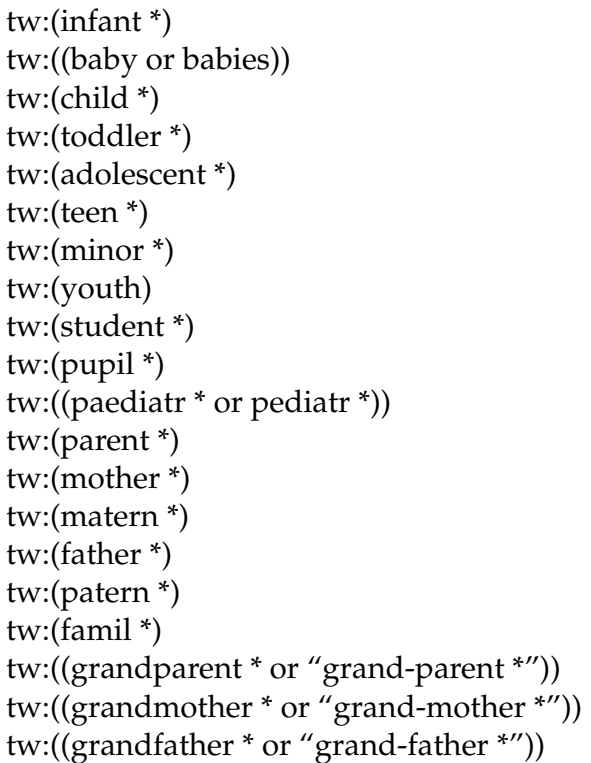 \\
\hline
\end{tabular}


Table A5. Cont.

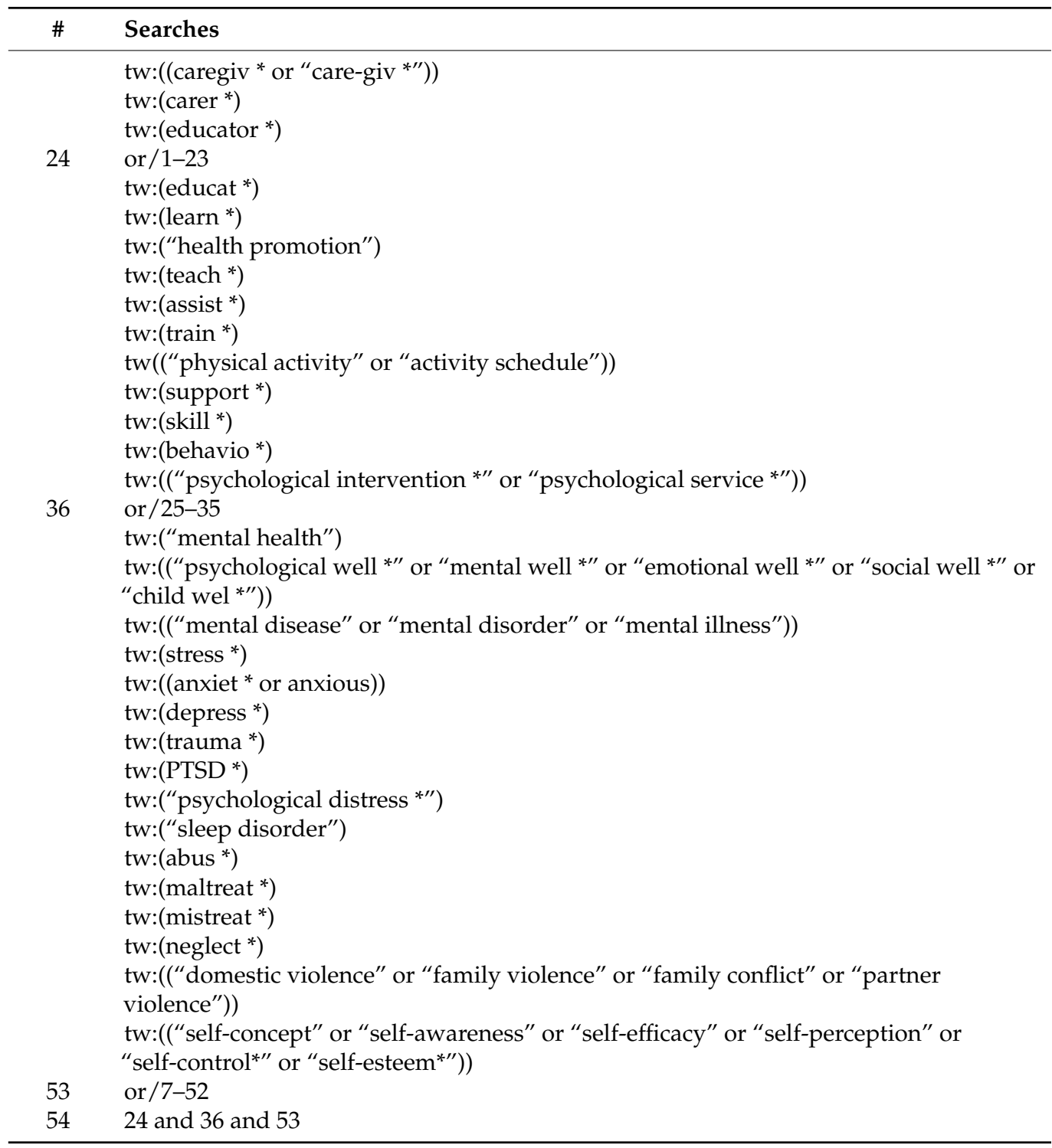

\section{Appendix F. Cochrane COVID-19 Study Register Search Strategy}

Database(s): Cochrane COVID-19 Study Register (https:/ / covid-19.cochrane.org/) 2020 Results: 434

Default search setting(s): interventional studies (clinical trials)

Table A6. Search strategy.

\begin{tabular}{ll}
\hline \# & Searches \\
\hline & Infant * \\
& baby or babies \\
& child * \\
& toddle * \\
& adolescent * \\
& teen * \\
& minor * \\
\hline
\end{tabular}


Table A6. Cont.

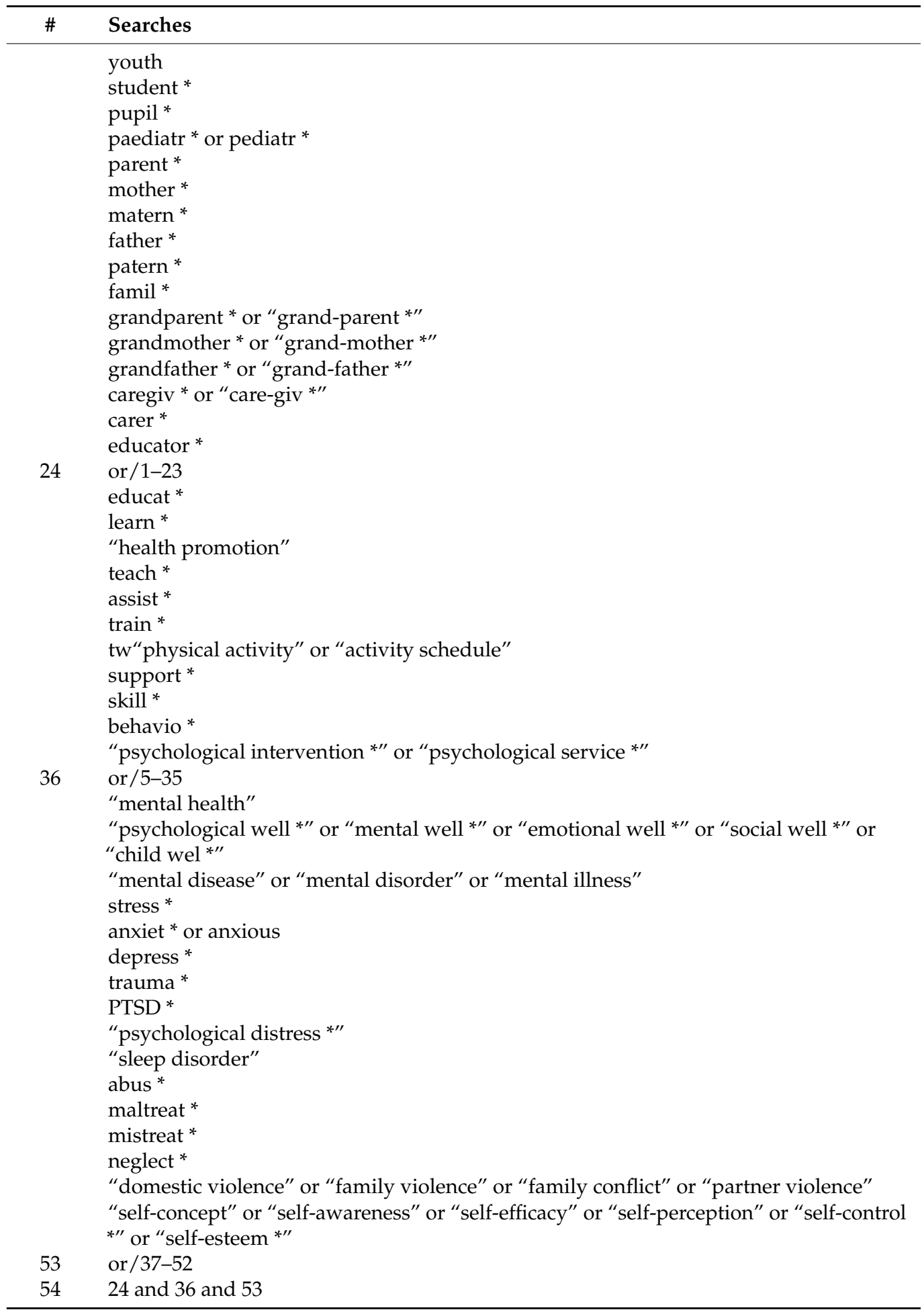

\section{Appendix G. ClinicalTrials.gov Search Strategy}

Database(s): ClinicalTrials.gov, National Institutes of Health (NIH) (https: / / clinicaltrials. gov) 2020

Results: 46

Default search setting(s): covid-19, child (birth-17), interventional studies (clinical trials) 
Table A7. Search strategy.

\begin{tabular}{ll}
\hline$\#$ & Searches \\
\hline & psychological \\
& mental \\
& emotional \\
& social \\
& stress \\
& anxiety \\
& depression \\
& trauma \\
& or/1-8 \\
\hline
\end{tabular}

\section{Appendix H. EU Clinical Trials Register Search Strategy}

Database(s): EU Clinical Trials Register (https:/ / www.clinicaltrialsregister.eu) 2020 Results: 19

Default search setting(s): Adolescent, children, infant and toddler, newborn, under 18 (age range)

Table A8. Search strategy.

\begin{tabular}{lll}
\hline$\#$ & Searches \\
\hline & adolescent \\
children & infant and toddler \\
& newborn \\
& under 18 \\
& or $/ 1-5$ \\
& covid-19 \\
6 & 6 and 7 \\
\hline
\end{tabular}

\section{Appendix I. German Clinical Trials Register (DRKS) Search Strategy}

Database(s): German Clinical Trials Register (DRKS) (https:/ /www.drks.de/drks_ web /) 2020

Results: 55

Default search setting(s): interventional studies (clinical trials)

Table A9. Search strategy.

\begin{tabular}{ll}
\hline$\#$ & Searches \\
\hline & $0-6$ years \\
& $7-14$ years \\
& $15-17$ years \\
4 & or $/ 1-3$ \\
& covid-19 \\
6 & 4 and 5 \\
\hline
\end{tabular}

\section{Appendix J. Data Extraction Form}

We used an electronic data extraction form in Microsoft Excel, which included the following items:

Study information:

- Author(s)

- Study title

- Publication year

- Study source (journal, report, pre-print publication) 
Study design:

- $\quad$ Study type (e.g., cross-sectional study, mixed methods)

- Objectives/purpose

Population/context:

- Population studied (characteristics, total number of participants)

- Region/country affected by disease outbreak

- Disease outbreak (e.g., COVID-19, H1N1 influenza)

- Study setting

- $\quad$ Pandemic control measure(s) in place (e.g., quarantine, school closure)

Intervention:

- $\quad$ Broad measure category (e.g., training, support group)

- Description of specific measure(s) (e.g., smartphone-based psychoeducation)

- Mode of delivery (e.g., online, face to face)

- Implementation of measure(s)

- Comparison group

- Comments

Outcomes:

- Outcome category (e.g., mental health)

- Description of outcome (e.g., depression)

- Link between intervention and outcome

- Follow-up

- Effect measure

- Total number of participants

- Outcome in the intervention group

- Participants in the intervention group

- Outcome in the comparison group

- Participants in the comparison group

- Comments

\section{References}

1. Brooks, S.K.; Webster, R.K.; Smith, L.E.; Woodland, L.; Wessely, S.; Greenberg, N.; Rubin, J.G. The psychological impact of quarantine and how to reduce it: Rapid review of the evidence. Lancet 2020, 395, 912-920. [CrossRef]

2. Mental Health and Psychosocial Support Aspects of the COVID-19 Response Interim Guidance. Available online: https: //iris.wpro.who.int/bitstream/handle/10665.1/14515/Mental-health-COVID-19-eng.pdf (accessed on 11 February 2021).

3. S3-Guideline Measures to Prevent and Control SARS-CoV-2 Transmission in Schools-Living Guideline. AWMF No 027076. Available online: https://www.awmf.org/uploads/tx_szleitlinien/027-076e_Praevention_und_Kontrolle_SARS-CoV2-Uebertragung_in_Schulen_2021-02.pdf (accessed on 7 February 2021).

4. Fegert, J.M.; Vitiello, B.; Plener, P.L.; Clemens, V. Challenges and burden of the Coronavirus 2019 (COVID-19) pandemic for child and adolescent mental health: A narrative review to highlight clinical and research needs in the acute phase and the long return to normality. Child. Adolesc. Psychiatry Ment Health 2020, 14, 1-11. [CrossRef] [PubMed]

5. Ravens-Sieberer, U.; Kamn, A.; Otto, C.; Adedeji, A.; Devine, J.; Erhart, M.; Napp, A.K.; Becker, M.; Blanck-Stellmacher, U.; Löffler, C.; et al. Mental health and quality of life in children and adolescents during the COVID-19 pandemic-results of the COPSY study. Dtsch. Ärztebl. Int. 2020, 117, 828-829.

6. Schlack, R.; Neuperdt, L.; Hölling, H.; de Bock, F.; Ravens-Sieberer, U.; Mauz, E.; Wachtler, B.; Beyer, A.K. Impact of the COVID-19 pandemic and the related containment measures on the mental health of children and adolescents. Available online: https:/ / edoc.rki.de/handle/176904/7551 (accessed on 7 February 2021).

7. Viner, R.; Russell, S.; Saulle, R.; Croker, H.; Stansfeld, C.; Packer, J.; Nicholls, D.; Goddings, A.L.; Bonell, C.; Hudson, L.; et al. Impacts of school closures on physical and mental health of children and young people: A systematic review. medRxiv 2021. [CrossRef]

8. Youth an COVID-19; Impacts On Jobs, Education, Rights And Mental Well-Being. ISBN 9789220328606. Available online: https: //www.ilo.org/wcmsp5/groups/public/---ed_emp/documents/publication/wcms_753026.pdf (accessed on 7 February 2020).

9. Abott A COVID's Mental-Health Toll: How Scientists Are Tracking A Surge in Depression. Researchers Are Using Huge Data Sets to Link Changes in Mental Health to Coronavirus-Response Measures. Available online: https://www.nature.com/articles/ d41586-021-00175-z (accessed on 3 February 2021). 
10. World Health Organization. Adolescent Mental Health. 2020. Available online: https://www.who.int/news-room/fact-sheets/ detail/adolescent-mental-health (accessed on 28 September 2020).

11. Patel, V.; Flisher, A.J.; Hetrick, S.; McGorry, P. Mental health of young people: A global public-health challenge. Lancet 2007, 369, 1302-1313. [CrossRef]

12. Kessler, R.C.; Angermeyer, M.; Anthony, J.C.; De Graaf, R.; Demyttenaere, K.; Gasquet, I.; De Girolamo, G.; Gluzaman, S.; Gureje, O.; Haro, J.M.; et al. Lifetime prevalence and age-of-onset distributions of mental disorders in the World Health Organization's World Mental Health Survey Initiative. World Psychiatry 2007, 6, 168-176. [PubMed]

13. Helping Children Cope with Stress during the 2019-nCoV Outbreak. Available online: https://www.who.int/docs/defaultsource/coronaviruse/helping-children-cope-with-stress-print.pdf?sfvrsn=f3a063ff_2 (accessed on 7 February 2020).

14. IASC Guidance on Operational Considerations for Multisectoral Mental Health and Psychosocial Support Programs during the COVID-19 Pandemic. Available online: https://interagencystandingcommittee.org/iasc-reference-group-mental-health-andpsychosocial-support-emergency-settings / my-hero-you (accessed on 29 May 2020).

15. American Psychological Association. APA COVID-19 Information and Resources. Available online: https://www.apa.org/ topics / covid-19 (accessed on 15 May 2020).

16. Ouzzani, M.; Hammady, H.; Fedorowicz, Z.; Elmagarmid, A. Rayyan-A web and mobile app for systematic reviews. Syst. Rev. 2016, 5, 210. [CrossRef]

17. Chen, S. An online solution focused brief therapy for adolescent anxiety during the novel coronavirus disease (COVID-19) pandemic: A structured summary of a study protocol for a randomised controlled trial. Trials 2020, 21, 402. [CrossRef]

18. Institute for Solution-Focused Therapy. What Is Solution-Focused Therapy? Available online: https://solutionfocused.net/whatis-solution-focused-therapy/ (accessed on 18 August 2020).

19. Zheng, Y. Reducing Eye Strain and Anxiety Using a Digital Intervention During Online Learning Class Recess Among Children at Home: A Randomized Controlled Trial (RESILIENT). ClinicalTrials.gov. 2020:NCT04309097. Available online: https:// clinicaltrials.gov/ct2/show / NCT04309097 (accessed on 15 July 2020).

20. Tymofiyeva, O. A Randomized Controlled Feasibility Study of Emotional Well-Being of Adolescents Undergoing a Mindfulness Training During the COVID-19 Pandemic. ClinicalTrials.gov. 2020:NCT04548544. Available online: https://clinicaltrials.gov/ct2 / show / NCT04548544 (accessed on 15 October 2020).

21. Henje Blom, E.; Duncan, L.G.; Ho, T.C.; Connolly, C.G.; LeWinn, K.Z.; Chesney, M.; Hecht, F.M.; Yang, T.T. The development of an RDoC-based treatment program for adolescent Depression.: “Training for Awareness, Resilience, and Action" (TARA). Front. Hum. Neurosci. 2014, 8, 630. [CrossRef]

22. Pavarini, G. Peer Support Training for Adolescents during the COVID-19 Outbreak: A Pilot Randomised Controlled trial. ISRCTN Registry. 2020:ISRCTN99248812. Available online: https:/ / www.isrctn.com/ISRCTN99248812 (accessed on 15 October 2020).

23. Green, S. Augmented Cognitive Behavioural Group Therapy for Perinatal Anxiety during a Global Pandemic (COVID-19). ClinicalTrials.gov. 2020:NCT04495803. Available online: https://www.clinicaltrials.gov/ct2/show/study/NCT04495803 (accessed on 15 October 2020).

24. Huang, H.F. The Effect of Internet-Based Cognitive Behavior Intervention on Perinatal Depression. and Anxiety during the Novel Noronavirus Pneumonia (COVID-19) Pandemic: A Multi-Center Randomized Controlled Trial. Chinese Clinical Trial Registry. 2020:ChiCTR2000033433. Available online: http:/ /www.chictr.org.cn/showproj.aspx?proj=54482 (accessed on 15 October 2020).

25. Monga, S. Mental Health Support for SickKids Children and Families during COVID-19 Using Established eHealth Interventions. ClinicalTrials.gov. 2020:NCT04408027. Available online: https://clinicaltrials.gov/ct2/show/NCT04408027 (accessed on 15 October 2020).

26. Ehrenreich-May, J. CO-PARENT: COVID-19-Parent Action in Response to Emotions and Needs for Treatment. ClinicalTrials.gov. 2020:NCT04431856. Available online: https:/ / clinicaltrials.gov/ct2/show/study/NCT04431856 (accessed on 15 October 2020).

27. Lin, X. Psychological Intervention for Parent-Child Relationship and Couple Relationship Under COVID-19 in China. ClinicalTrials.gov. 2020: NCT04463433. Available online: https:/ / clinicaltrials.gov/ct2/show/NCT04463433. (accessed on 15 October 2020).

28. Miklósi, M. Online parent training for reducing parenting stress during the COVID-19 pandemic: A randomized controlled trial. ISRCTN Registry. 2020:ISRCTN15254871. Available online: https:/ / www.isrctn.com/ISRCTN15254871 (accessed on 15 October 2020).

29. Francis, L. Adapting and Delivering a Tele-Wellness Supported Digital Toolkit to Baltimore City's Approved Family Child Care Home Providers Caring for Children of Essential Workers: Promoting Health, Early Literacy, and Quality Parent Engagement Amid COVID-19: A Pilot Study. ClinicalTrials.gov. 2020:NCT04453657. Available online: https:/ / clinicaltrials.gov/ct2/show/NCT04453657 (accessed on 15 October 2020).

30. Chung, G.; Lanier, P.; Wong, P.Y.J. Mediating Effects of Parental Stress on Harsh Parenting and Parent-Child Relationship during Coronavirus (COVID-19) Pandemic in Singapore. J. Fam. Violence 2020. [CrossRef] [PubMed]

31. Groh, A.M.; Roisman, G.I.; van Ijzendoorn, M.H.; Bakermans-Kranenburg, M.J.; Fearon, R.P. The significance of insecure and disorganized attachment for children's internalizing symptoms: A meta-analytic study. Child Dev. 2012, 83, 591-610. [CrossRef] [PubMed]

32. Fearon, R.P.; Bakermans-Kranenburg, M.J.; van Ijzendoorn, M.H.; Lapsley, A.M.; Roisman, G.I. The significance of insecure attachment and disorganization in the development of children's externalizing behavior: A meta-analytic study. Child Dev. 2010, 81, 435-456. [CrossRef] 
33. Wisner, K.L.; Miller, E.S.; Tandon, D. Attention to Prevention-Can We Stop Perinatal Depression. before It Starts? JAMA Psychiatry 2019, 76, 355-356. [CrossRef] [PubMed]

34. Cobham, V.E.; McDermott, B.; Haslam, D.; Sanders, M.R. The Role of Parents, Parenting and the Family Environment in Children's Post-Disaster Mental Health. Curr. Psychiatry Rep. 2016, 18, 53. [CrossRef] [PubMed]

35. Sigurvinsdóttir, A.L.; Jensínudóttir, K.B.; Baldvinsdóttir, K.D.; Smárason, O.; Skarphedinsson, G. Effectiveness of cognitive behavioral therapy (CBT) for child and adolescent anxiety disorders across different CBT modalities and comparisons: A systematic review and meta-analysis. Nord J. Psychiatry 2020, 74, 168-180. [CrossRef]

36. Grist, R.; Croker, A.; Denne, M.; Stallard, P. Technology Delivered Interventions for Depression. and Anxiety in Children and Adolescents: A Systematic Review and Meta-analysis. Clin. Child Fam. Psychol. Rev. 2019, 22, 147-171. [CrossRef] [PubMed]

37. Ruggiero, K.J.; Price, M.; Adams, Z.; Stauffacher, K.; McCauley, J.; Danielson, C.K.; Knapp, R.; Hanson, R.F.; Davidson, T.M.; Amstadter, A.B.; et al. Web Intervention for Adolescents Affected by Disaster: Population-Based Randomized Controlled Trial. J. Am. Acad. Child Adolesc. Psychiatry 2015, 54, 709-717. [CrossRef] [PubMed]

38. Zhang, A.; Franklin, C.; Currin-McCulloch, J.; Park, S.; Kim, J. The effectiveness of strength-based, solution-focused brief therapy in medical settings: A systematic review and meta-analysis of randomized controlled trials. J. Behav. Med. 2018, 41, 139-151. [CrossRef]

39. Henje, B.E.; Tymofiyeva, O.; Chesney, M.A.; Ho, T.C.; Moran, P.; Connolly, C.G.; Duncan, L.G.; Baldini, L.; Weng, Y.H.; Acree, M.; et al. Feasibility and Preliminary Efficacy of a Novel RDoC-Based Treatment Program for Adolescent Depression.: "Training for Awareness Resilience and Action" (TARA)-A Pilot Study. Front. Psychiatry 2016, 7, 208. [CrossRef]

40. Daks, J.S.; Peltz, J.S.; Rogge, R.D. Psychological flexibility and inflexibility as sources of resiliency and risk during a pandemic: Modeling the cascade of COVID-19 stress on family systems with a contextual behavioral science lens. J. Contextual Behav. Sci. 2020, 18, 16-27. [CrossRef]

41. Tarver, J.; Daley, D.; Lockwood, J.; Sayal, K. Are self-directed parenting interventions sufficient for externalising behaviour problems in childhood? A systematic review and meta-analysis. Eur. Child. Adolesc. Psychiatry 2014, 23, 1123-1137. [CrossRef]

42. Comer, J.S.; Furr, J.M.; Miguel, E.M.; Cooper-Vince, C.E.; Carpenter, A.L.; Elkins, R.M.; Kerns, M.; Cornacchio, C.E.; Chou, D.; Coxe, T.; et al. Remotely delivering real-time parent training to the home: An initial randomized trial of Internet-delivered parent-child interaction therapy (I-PCIT). J. Consult. Clin. Psychol. 2017, 85, 909-917. [CrossRef] [PubMed]

43. Baker, S.; Sanders, M.R.; Turner, K.M.T.; Morawska, A. A randomized controlled trial evaluating a low-intensity interactive online parenting intervention, Triple P Online Brief, with parents of children with early onset conduct problems. Behav. Res. Ther. 2017, 91, 78-90. [CrossRef] [PubMed]

44. Stubbs, B.; Vancampfort, D.; Rosenbaum, S.; Firth, J.; Cosco, T.; Veronese, N.; Salum, A.G.; Schck, F.B. An examination of the anxiolytic effects of exercise for people with anxiety and stress-related disorders: A meta-analysis. Psychiatry Res. 2017, 249, 102-108. [CrossRef] [PubMed]

45. Dale, L.P.; Vanderloo, L.; Moore, S.; Faulkner, G. Physical activity and Depression Anxiety, and self-esteem in children and youth: An umbrella systematic review. Ment Health Phys. Act. 2019, 16, 66-79. [CrossRef]

46. Hoffmann, B.; Kobel, S.; Wartha, O.; Kettner, S.; Dreyhaupt, J.; Steinacker, J.M. High sedentary time in children is not only due to screen media use: A cross-sectional study. BMC Pediatr. 2019, 19, 154. [CrossRef] [PubMed]

47. Guerrero, M.D.; Vanderloo, L.M.; Rhodes, R.E.; Faulkner, G.; Moore, S.A.; Tremblay, M.S. Canadian children's and youth's adherence to the 24-h movement guidelines during the COVID-19 pandemic: A decision tree analysis. J. Sport Health Sci. 2020, 9, $313-321$. [CrossRef] [PubMed]

48. Xiang, M.; Zhang, Z.; Kuwahara, K. Impact of COVID-19 pandemic on children and adolescents' lifestyle behavior larger than expected. Prog. Cardiovasc. Dis. 2020, 63, 531-532. [CrossRef] [PubMed]

49. Moore, S.; Faulkner, G.; Rhodes, R.; Brussoni, M.; Chulak-Bozzer, T.; Ferguson, L.; Mitra, R.; O’Reilly, N.; Spence, J.C.; Vanderloo, L.M.; et al. Impact of the COVID-19 virus outbreak on movement and play behaviours of Canadian children and youth: A national survey. Int. J. Behav. Nutr. Phys. Act. 2020, 17, 85. [CrossRef]

50. Skokauskas, N.; Leventhal, B.; Cardeli, E.L.; Belfer, M.; Kaasbøll, J.; Cohen, J. Supporting children of healthcare workers during the COVID-19 pandemic. Eur. Child Adolesc. Psychiatry 2020, 18, 1-2. [CrossRef]

51. Loades, M.E.; Chatburn, E.; Higson-Sweeney, N.; Reynolds, S.; Shafran, R.; Brigden, A.; Linney, C.; Niamh, M.; Boewick, C.; Crawley, E. Rapid Systematic Review: The Impact of Social Isolation and Loneliness on the Mental Health of Children and Adolescents in the Context of COVID-19. J. Am. Acad. Child. Adolesc. Psychiatry 2020, 59, 1218-1239.e3. [CrossRef] [PubMed]

52. Ali, K.; Farrer, L.; Gulliver, A.; Griffiths, K.M. Online Peer-to-Peer Support for Young People with Mental Health Problems: A Systematic Review. JMIR Ment. Health. 2015, 2, e19. [CrossRef] [PubMed]

53. Ramsey, W.; Heidelberg, R.; Gilbert, A.; Heneghan, M.; Badawy, S.; Alberts, N. eHealth and mHealth Interventions in Pediatric Cancer: A Systematic Review of Interventions across the Cancer Continuum. Psychooncology 2020, 29, 17-37. [CrossRef]

54. Badawy, S.M.; Barrera, L.; Sinno, M.G.; Kaviany, S.; O’Dwyer, L.C.; Kuhns, L.M. Text Messaging and Mobile Phone Apps as Interventions to Improve Adherence in Adolescents with Chronic Health Conditions: A Systematic Review. JMIR Mhealth Uhealth. 2017, 5, e66. [CrossRef] [PubMed]

55. American Academy of Child and Adolescent Psychiatry (AACAP) Committee on Telepsychiatry and AACAP Committee on Quality Issues. Clinical Update: Telepsychiatry with Children and Adolescents. J. Am. Acad. Child. Adolesc. Psychiatry 2017, 56, 875-893. [CrossRef] 
56. Gloff, N.E.; LeNoue, S.R.; Novins, D.K.; Myers, K. Telemental health for children and adolescents. Int. Rev. Psychiatry 2015, $27,513-524$. [CrossRef] [PubMed]

57. Langarizadeh, M.; Tabatabaei, M.S.; Tavakol, K.; Naghipour, M.; Rostami, A.; Moghbeli, F. Telemental Health Care, an Effective Alternative to Conventional Mental Care: A Systematic Review. Acta Inf. Med. 2017, 25, 240-246. [CrossRef]

58. Perrin, P.B.; Rybarczyk, B.D.; Pierce, B.S.; Jones, H.A.; Shaffer, C.; Islam, L. Rapid telepsychology deployment during the COVID-19 pandemic: A special issue commentary and lessons from primary care psychology training. J. Clin. Psychol. 2020, 76, 1173-1185. [CrossRef] [PubMed]

59. Badawy, S.M.; Radovic, A. Digital Approaches for Remote Pediatric Healthcare Delivery during the Coronavirus (Covid-19) Pandemic: Existing Evidence and a Call for Further Research. J. Med. Internet Res. Pediatrics Parent. 2020, 3, e20049. [CrossRef]

60. MacEvilly, D.; Brosnan, G. Adapting an emotional regulation and social communication skills group programme to teletherapy, in response to the Covid-19 pandemic. Ir. J. Psychol. Med. 2020. [CrossRef] [PubMed]

61. Roca, E.; Melgar, P.; Gairal-Casadó, R.; Pulido-Rodríguez, M.A. Schools That 'Open Doors' to Prevent Child Abuse in Confinement by COVID-19. Sustainability 2020, 12, 4685. [CrossRef]

62. Center on the Developing Child at Harvard University. Building Core Capabilities for Life-The Science Behind the Skills Adults Need to Succeed in Parenting and in the Workplace. Available online: https://developingchild.harvard.edu/resources/buildingcore-capabilities-for-life/ (accessed on 25 October 2020).

63. UN Women. Issue Brief: COVID-19 and Ending Violence against Women and Girls. Available online: https:/ /www.unwomen. org/en/digital-library/publications/2020/04/issue-brief-covid-19-and-ending-violence-against-women-and-girls (accessed on 25 October 2020).

64. Emezue, C. Digital or Digitally Delivered Responses to Domestic and Intimate Partner Violence during COVID-19. JMIR Public Health Surveill. 2020, 6, e19831. [CrossRef]

65. Slyer, J.T. Unanswered questions. J. Biomed. Inform. Database Syst. Rev. Implement. Rep. 2016, 14, 1-2. [CrossRef] [PubMed]

66. Yaffe, J.; Montgomery, P.; Hopewell, S.; Shepard, L.D. Empty reviews: A description and consideration of Cochrane systematic reviews with no included studies. PLoS ONE 2012, 7, e36626. [CrossRef] [PubMed] 